\title{
Morphological Diversity of Populations of the Genus Prosopis in the Semiarid Chaco of Northern Cordoba and Southern Santiago Del Estero
}

\author{
Marisa Jacqueline Joseau ${ }^{1 *}$, Aníbal Ramón Verga ${ }^{2}$, María del Pilar Díaz ${ }^{3}$, Norma Beatríz Julio ${ }^{4}$ \\ ${ }^{1}$ Department of Forestry, Faculty of Agricultural Science, National University of Cordoba (UNC), Córdoba, Argentina; ${ }^{2}$ Institute of \\ Physiology and Plant Genetic Resources (IFRGV), Agricultural Research Center (CIAP), National Institute of Agricultural \\ Technology (INTA), Córdoba, Argentina; ${ }^{3}$ Statistics and Biostatistics. School of Nutrition, Faculty of Medical Sciences, UNC, \\ Córdoba, Argentina; ${ }^{4}$ Population Genetics and Evolution, Faculty of Exact, Physical and Natural Sciences, UNC, Córdoba, Argen- \\ tina. \\ Email: ${ }^{*}$ jajoseau@agro.unc.edu.ar
}

Received January $13^{\text {th }}, 2013$; revised February $13^{\text {th }}, 2013$; accepted March $15^{\text {th }}, 2013$

Copyright (C) 2013 Marisa Jacqueline Joseau et al. This is an open access article distributed under the Creative Commons Attribution License, which permits unrestricted use, distribution, and reproduction in any medium, provided the original work is properly cited.

\begin{abstract}
The objective of this study consisted in the characterization of morphological variability presented in the Prosopis population in the corridor that unites the semiarid with the arid region in Argentina. In this region, four species of Prosopis get in contact ( $P$. chilensis, $P$. flexuosa, $P$. alba and $P$. nigra). Due to the fact that these species make fertile hybrids, this corridor has an enormous diversity. The mother's allowed the differentiation of five morphologic groups, which from the point of view of classic taxonomy have been classified in 16 taxa. Only groups 3 and 4 presented intermediate characteristics. The morphologic study of the descendants showed that the regrouping of the intermediate groups had a high error rate. This fact reaffirms the condition of intermediate groups. The canonical correlation analysis between the morphologic variables of the mothers and the seedlings revealed that each morphologic group had its own association of canonical variables between mothers and their seedlings, and that the variability observed in the set of the mothers and their seedlings follows a certain order. The enormous existing morphologic diversity in the Prosopis populations of the semi-arid Chaco of the north of Córdoba and southeast of Santiago del Estero was ordered in five morphologic groups. The descendant's morphologic studies confirmed the existence of the defined morphologic-genetic groups.
\end{abstract}

Keywords: Algarrobo; Morphological Groups; Hybrid Swarm; Semi-Arid and Arid Chaco

\section{Introduction}

Widespread deforestation and declining condition of the global forest resulted in an environmentally, economically and aesthetically impoverished landscape [1]. Argentina is no exception as it has lost $70 \%$ of its native forests over the last 114 years [2].

The change in forest cover, its quality and composition have influenced the size and nature of genetic variation in forest trees [3]. Some tree species of the genus Prosopis are of great economic and ecological interest among the trees in Argentina. Only relict of the once wide forest of Prosopis remain and the irrational exploitation generates genetic impoverishment, with alarming loss of biodiversity [4].

*Corresponding author.
The genus Prosopis Linnaeus emend. Burkart is within the family Fabaceae (Leguminosae), subfamily Mimosoideae [5]. Based on differences in floral and vegetative features, Burkart [6] defined the generic limits and divided the genus into five sections and within the Algarobia section identified 5 separate series according to the type of vegetative growth. While the generic limits and the division into sections are generally accepted, there are debates as to the range in terms of species as Burkart defined [6]. Being the most recent and complete taxonomical classification of the genus [5], this is taken as the basis in this work. Thus the species studied in this research belong to Algarobia section Chilenses series.

In Burkart classification [6], 44 species and 27 varieties of Prosopis are listed. The existence of populations of Prosopis with distinct characteristics led Burkart to 
describe many as separate species or varieties, even though several are known to hybridise [5]. Of the five sections distributed in arid and semiarid regions of Africa, America and West Asia, three are present in the Argentine territory: the Strombocarpa, Monilicarpa and Algarobia sections with a total 27 species; 21 of them belong to Algarobia section [7].

The close semiarid region located between the foothills of the Sierras de Córdoba and those of Sumampa in Santiago del Estero and Salinas Grandes, in both provinces forms a narrow corridor linking the semiarid Chaco with the arid Chaco. In this corridor, species typical of semiarid Chaco Prosopis described as Prosopis alba and $P$. nigra penetrate from the North, while P. flexuosa, $P$. chilensis, species dominant in arid Chaco penetrate from the South. In this region individuals of intermediate morphology that could correspond to interspecific hybrids are observed and constitute part of hybrid swarm among these four species.

Thus, this area clearly defined by geographical features (mountains and saltworks) would be one of the main centres of diversity (if not the most important) of genus Prosopis in Argentina

There are hybrid swarms in many groups of plants. In woody plants this has been described in the genus Juniperus, Quercus, Aesculus, Eucalyptus y Opuntia [8] and more recently in the genus Prosopis [9-13]. The taxonomy of the genus is quite problematic [10]. The problems of the limitation of species in this genus are found mostly in Algarobia Section. Apparently the clear absence of reproductive isolation barriers between species [9,14-17] and the sympatry $[6,18,19]$ facilitated the hybridization and introgression and contributed to the observed morphological and genetic variability in populations $[19,20]$.

Species linked by frequent or occasional hybridization are a singameon. This was defined by Grant [8] as a group of species that hybridize and act as a biological species, reproductively isolated from other similar groups. Given the ability of some species hybridization of Section Algarobia (P. alba, P. nigra, P. chilensis y P. flexuosa) some authors $[9,21,22]$ suggested that they constitute a singameon, which makes it difficult to identify them in the field.

Previous studies in Section Algarobia, chromatographics $[9,14,23,24]$, seminal protein electrophoresis $[25,26]$ and isoenzyme electrophoresis [11,21,27-30] indicated a low degree of differentiation between species, which could be explained by frequent hybridization between them in an area of sympatry, favored by weak isolation barriers and environmental modifications [4]. However, morphological taxonomic studies indicate a strong differentiation between the different species $[6,11,23]$.

This apparent contradiction is generated because there are individuals who truly represent the species listed, which are even clearly different, both morphologically and ecologically. When studying individuals in regions where species come into contact, a large number of intermediate individuals sprang up that cannot be clearly classified in any of the species. This leads to the conclusion that the result will depend on the used criterion for selecting individuals that will represent the species in question. If one includes only those who strictly respond to the characteristics of the pure species, differentiation between them will be important and the intraspecific variation genetic and morphological will be minor. As more individuals intermediate are added, responding in part to the characteristics of the species, this becomes unclear with respect to the other species, decreasing in differentiation and increasing in diversity [12].

The hybridization of the environment that occurs due to human activity such as road construction, agriculture, irrigation and forestry $[8,9,31]$ is one of the conditions that encourage the establishment of hybrids $[8,9]$.

The "algarrobos" present in the contact area of Prosopis chilensis-P. flexuosa-P. alba-P. nigra in the semiarid Chaco of the North of Cordoba and the South of Santiago del Estero are apparently shown as a continuum from the morphological point of view. In many cases it is impossible to classify a particular individual in any of the species mentioned, because their morphological characters correspond to more than one species simultaneously, making it almost impossible for his taxonomic classification.

However it is possible that, within this apparent continuum, there are groups of individuals that resemble closer among themselves and are away from the pure species mentioned, constituting genetic units with adaptation to specific niches appearing in these environments hybrids.

Identifying the groups that these individuals can form from the point of view of morphological characters ("morphological groups defined") will serve as a starting point to select genetic units of the hybrid swarm, which retain their adaptive traits and productivity in their offspring and become so in the basis for the improvement and use of these genetic resources.

Hybrid areas constitute a reservoir of variation of importance to conservation and may be used as base material for breeding programmes in the long term while the areas of "pure species", though presented less variation, surely have greater stability and adaptation to "normal" conditions, being able to provide base material for use in the short term $[12,32]$.

The availability of appropriate genetic material, together with a better understanding of intraspecific variation in tree species, is a requirement for the development and domestication of these species $[33,34]$. The aim was 
to characterize the morphological variation existing in populations of Prosopis in the Semiarid Chaco of northern Córdoba and southern Santiago del Estero.

\section{Materials and Methods}

The materials for this research were seed and branches of Prosopis chilensis, P. alba, P. flexuosa, P. nigra and intermediate individuals, possible hybrids among these four species in the Semiarid Chaco of northern Córdoba and southern of Santiago del Estero.

\subsection{Exploration}

In the late 1999 and early 2000 four areas (populations) were identified based on the gradients of temperature and precipitation in the Chaco Semiarid, in northern of Córdoba and southern of Santiago del Estero to get the study material (Prosopis individuals most characteristic in the contact area Prosopis chilensis-P. flexuosa-P. alba-P. nigra), following the direction of the corridor (northeast-southwest). In addition to these gradients, there were spatial discontinuities in the apparition of species of the genus or start of the others not included in this study. Thus, four samples were defined: Jume-Los Telares $\left(Z_{1}\right)$ was defined to the town of Los Telares since moving further North individuals of $P$. ruscifolia, a species completely different from the morphological point of view began to be seen (Table 1 and Figures 1(a) and (b)).

The second was located near the Salinas Grandes: San José de Las Salinas-Lucio V. Mansilla $\left(\mathrm{Z}_{2}\right)$, the third zone was established in an ecotone between two biogeographic subregions: Quilino-Huascha $\left(Z_{3}\right)$ and the fourth was the most southern point of the corridor where trees of Prosopis with pods were: Cruz del Eje-Tuclame $\left(\mathrm{Z}_{4}\right)$ (Table 1 and Figures 1(a) and (b)).

Table 1. Quantity and location of harvested trees.

\begin{tabular}{|c|c|c|c|c|c|c|c|}
\hline \multirow[t]{2}{*}{ Zone } & \multirow[t]{2}{*}{ Latitude } & \multirow[t]{2}{*}{ Longitude } & \multirow[t]{2}{*}{ Altitude (msnm) } & \multirow[t]{2}{*}{$\mathrm{A}(\mathrm{mm})$} & \multicolumn{2}{|c|}{$\mathrm{B}\left({ }^{\circ} \mathrm{C}\right)$} & \multirow{2}{*}{ Individuals total per zone } \\
\hline & & & & & The hottest & The coldest & \\
\hline $\mathrm{Z}_{1}$ & $28^{\circ} 59^{\prime}-29^{\circ} 23^{\prime}$ & $63^{\circ} 26^{\prime}-63^{\circ} 41^{\prime}$ & $108-480$ & $597-600$ & 26.9 & 11.5 & 27 \\
\hline $\mathrm{Z}_{2}$ & $29^{\circ} 47^{\prime}-30^{\circ} 08^{\prime}$ & $63^{\circ} 42^{\prime}-64^{\circ} 31^{\prime}$ & $191-193$ & $394-453$ & 27.7 & 12.5 & 15 \\
\hline$Z_{3}$ & $30^{\circ} 12^{\prime}-30^{\circ} 36^{\prime}$ & $64^{\circ} 24^{\prime}-64^{\circ} 46^{\prime}$ & $393-689$ & $445-560$ & 26.2 & 10.8 & 23 \\
\hline $\mathrm{Z}_{4}$ & $29^{\circ} 38^{\prime}-30^{\circ} 45^{\prime}$ & $64^{\circ} 38^{\prime}-65^{\circ} 14^{\prime}$ & $275-600$ & $379-481$ & 27.6 & 11.5 & 20 \\
\hline
\end{tabular}

Source: [43]. A = Average annual rainfall; $\mathrm{B}=$ Average monthly temperature.
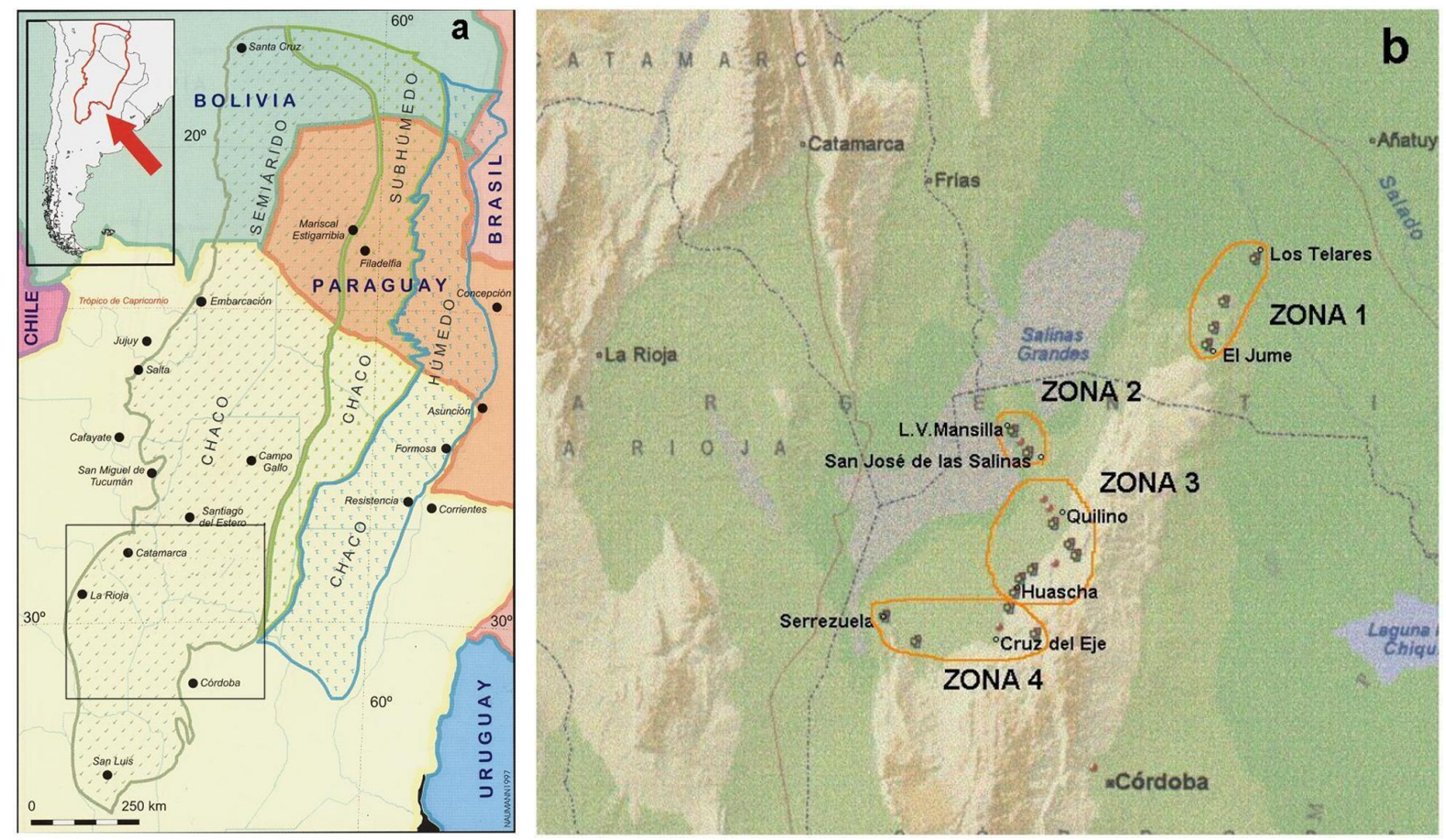

Figure 1. Location: (a) Chaco Phytogeographic Province [37] and (b) Study area. 


\subsection{Samples}

This study sought to achieve order and classification of the genus Prosopis species found in the region, whose morphological variability appears in first as a continuum, in biological separated units to make handling possible.

Four areas were selected located at different lattitudes with different environmental characteristics and usage, representing the different conditions that occur in this geographical corridor. In each area or population sought to capture the great variability of possible shapes unbiased manner, providing that individuals submit pods mature and intact from the morphological viewpoint. It is worth mentioning that individuals with faulty leaflets resulting from the use of herbicide application in nearby fields were not harvested.

\subsection{Harvest}

Table 1 shows the number of individuals harvested according to zones. The total amount of trees harvest was 85. Located at each harvested individual by geographic positioning (GPS). Measurements considering height, stem diameter and canopy, were classified by age group and health status, following the methodology and harvest forms of National Germplasm Bank of Prosopis (BNGP) of FCA-UNC [35]. A harvested tree was assigned a number from 1 to 85 (Table 2) and at harvest time the species it belongs to was not specified.
The fruits threshed and seeds obtained after being dried were placed in a freezer for ten days to bruchid control [36], later stored at $4^{\circ} \mathrm{C}$ in sealed jars retaining their identification.

From each accession fruits and two branches with mature leaves were taken off, material to herbaria, to do morphological studies under two different classifications: classical classification and numerical taxonomy. So, the 85 herbaria samples collected were sent to the Laboratory of Vascular Plants of the Buenos Aires National University for identification based on pre-established taxonomic criteria for the differentiation of pure species. As a result of this classification 16 taxa were obtained (Table 2). Notably, in this identification, any pure species of Prosopis flexuosa were present in the sample.

On the other hand morphological analysis was carried out based on numerical taxonomy whose methodology is detailed below. To order mother plants taxonomically, morphological analysis was conducted and, based on the obtained clustering; later analysis on the progeny was done.

The zones are located in the Chaco Phytogeographic Province (Gran Chaco) [37-40]; more exactly in the Semiarid Chaco Subregion [37,38].

The main pocket is constituted by a geographical corridor whose boundaries both Cordoba and Santiago del Estero are Salinas Grandes towards the West and the Sierras towards the North and East. This pocket is limited

Table 2. Identification of mother plants through classical taxonomy.

\begin{tabular}{|c|c|c|c|}
\hline Species & Symbol & Number of the parent plant & Total individuals \\
\hline P. alba & $\mathrm{Pa}$ & $11-12-18-20-26-84$ & 6 \\
\hline P. alba (folíolos algo menores) & $\mathrm{Pa}_{\mathrm{fm}}$ & 23 & 1 \\
\hline P. alba $x^{*}$ & Pax? & $2-31-39-52$ & 4 \\
\hline P. alba $\times$ P. nigra & Paxn & 22 & 1 \\
\hline P. alba ó $P$. chilensis $x$ P. flexuosa. & Paxf & 41 & 1 \\
\hline P. chilensis $\times$ P. alba & Pcxa & $1-4-5-8-24-36$ & 6 \\
\hline P. chilensis & Pc & $19-35-37-43-44-46-50-51-55-56-59-60-61-62-63-64-65-66-69-70-74-77-79-80-82$ & 25 \\
\hline P. chilensis (folíolos algo menores) & $\mathrm{Pc}_{\mathrm{fm}}$ & $10-17-32-33-38-42-45-57-78$ & 9 \\
\hline P. chilensis $x^{*}$ & Pcx? & $27-40$ & 2 \\
\hline P. chilensis $x P$. flexuosa & Pcxf & $81-83$ & 2 \\
\hline$P$. chilensis $x P$. flexuosa o $P$. nigra & Pcxfon & $68-75-76$ & 3 \\
\hline P. chilensis $\times$ P. ruscifolia & Pcxr & 21 & 1 \\
\hline P. ruscifolia & $\operatorname{Pr}$ & 25 & 1 \\
\hline P. flexuosa o P. flexuosa x P. alba & Pf o Pfxa & $3-6$ & 2 \\
\hline$P$. flexuosa o $P$. nigra $x$ P. chilensis & Pfxc & 53 & 1 \\
\hline P. nigra & Pn & $7-9-13-14-15-16-28-30-34-48-49-54-58-67-71-72-73-85$ & 18 \\
\hline Unidentified & S/ident. & $29-47$ & 2 \\
\hline Total taxa & 16 & & 85 \\
\hline
\end{tabular}

Reference: ${ }^{*}$ unidentified for lack of reproductive material. 
in the Sierras de Cordoba by Sierras of La Higuerita, of Orcosuni, of Sauce Puncu, San Pedro Norte and Ambargasta [41], while the latter and Sumampa chain are found in Sanitago del Estero. All of these mountains have a North-South direction [41,42].

Chains of Sumampa and Ambargasta in Santiago del Estero are merely an extension of the Sierras de Córdoba. Their length within the province of Santiago del Estero is 60 kilometres and the transverse extension of two strings together is about 40 kilometres [42].

Desertification caused by the degradation of soil and vegetation is rated moderate to severe depending on the area [37].

These areas constitute what in this work are set to study populations. At harvest time, the identification of the specimens sample was established by a number. From the consulted bibliography, of data recorded on the form of National Bank of germplasm of Prosopis, using the classical classification the following description of each area is provided, which has no other purpose rather than to describe the situation in which each region was at the moment of sampling. The expansion of the agricultural frontier in recent years due to the cultivation of soya may have changed some features of each study population.

\subsection{1. $\mathrm{Z}_{1}$. El Jume-Los Telares (Santiago Del Estero)}

This region is located in the phytogeographic region of western Chaco. The altitude varies from 108 to 480 masl and average annual rainfall is about $600 \mathrm{~mm}$. This region is partially disassembled (Table 1).

From the point view of classical taxonomy, the sample in this area consisted of 11 taxa, including six which were made up of pure species (P. alba, P. alba with minor leaflet, $P$. chilensis, $P$. chilensis with leaflet minor, $P$. nigra and P.ruscifolia) and the rest (39\%) were intermediate taxa (Figures 2 and $\mathbf{3}$ ).

If the age composition of the sample is observed, it shows that the most frequent carobs were elderly P. alba and young individuals of $P$. nigra. Among the intermediate taxa mature individuals were predominant, which

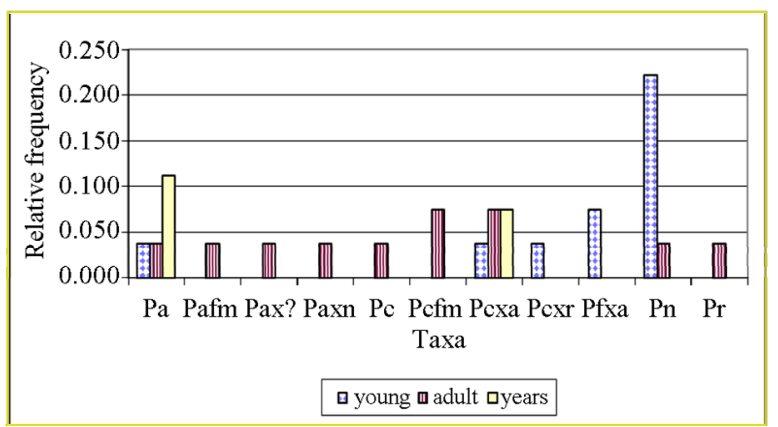

Figure 2. Relative frequency distribution of the taxa present in $\mathrm{Z}_{1}$ according to age. would indicate that the hybridization process in this region would not be recent.

The presence of greater numbers of young individuals of $P$. nigra would coincide with the views expressed by various authors $[42,44]$, in that it is an unpalatable species and therefore it thrives in degraded forest areas.

It is important to notice that the intermediate taxon classified as $P$. chilensis $\times$ P. alba presented three age groups.

\subsection{2. $\mathrm{Z}_{2}$. Lucio V. Mansilla-San Jose de Las Salinas (Córdoba)}

This area is near the Salinas Grandes, the altitude is between 190 and 195 masl and average annual rainfall ranges from 394 to $453 \mathrm{~mm}$.

Taxa diversity in the sample was lower than in $Z_{1}$. Out of 6 taxa found, three belonged to pure species: $P$. chilensis, $P$. chilensis (leaflets somewhat smaller) and $P$. nigra and the rest were mainly composed of hybrids among white carobs (Figures 3 and $\mathbf{4 ( a )}$ ).

The age composition of the sample in this zone indicates a predominance of adult individuals, and in this case young trees relate only to intermediate individuals and $P$. nigra (Figure 4(a)).

\subsubsection{Z $Z_{3}$ Quilino-Huascha (Córdoba)}

In this area individuals belonging to 7 different taxa were harvested. Three belonging to pure species: P. chilensis, $P$. chilensis with leaflets somewhat smaller, $P$. nigra and four intermediate individuals, classified by Engineer Palacios as carob hybrids mainly between blacks and whites (Figures 3 and 4(b)). The species most commonly identified in three stages (young, adult and years) was $P$. chilensis (Figure 4(b)).

As for the age composition there was a predominance of adult and elderly, only young individuals in the case of $P$. chilensis and $P$. nigra were observed.

\subsubsection{Z $\mathrm{Z}_{4}$. Cruz Del Eje-Tuclame (Córdoba)}

The area has been quite altered by human activity, as there are various agricultural crops such as citrus, grapes and olives.

Harvested Prosopis species were $P$. chilensis, $P$. chilensis (with leaflets somewhat smaller) and P. nigra. Found hybrids were made of $P$. chilensis with $P$. flexuosa or $P$. nigra, in the adult stage or years. This area is the one which presented fewer taxa (5) (Figures 3 and 4(c)).

The species that showed more often in the sample were elderly individuals of $P$. chilensis and adults $P$. nigra.

\subsection{Morphological Analysis}

The morphological analysis, using the principles of nu- 


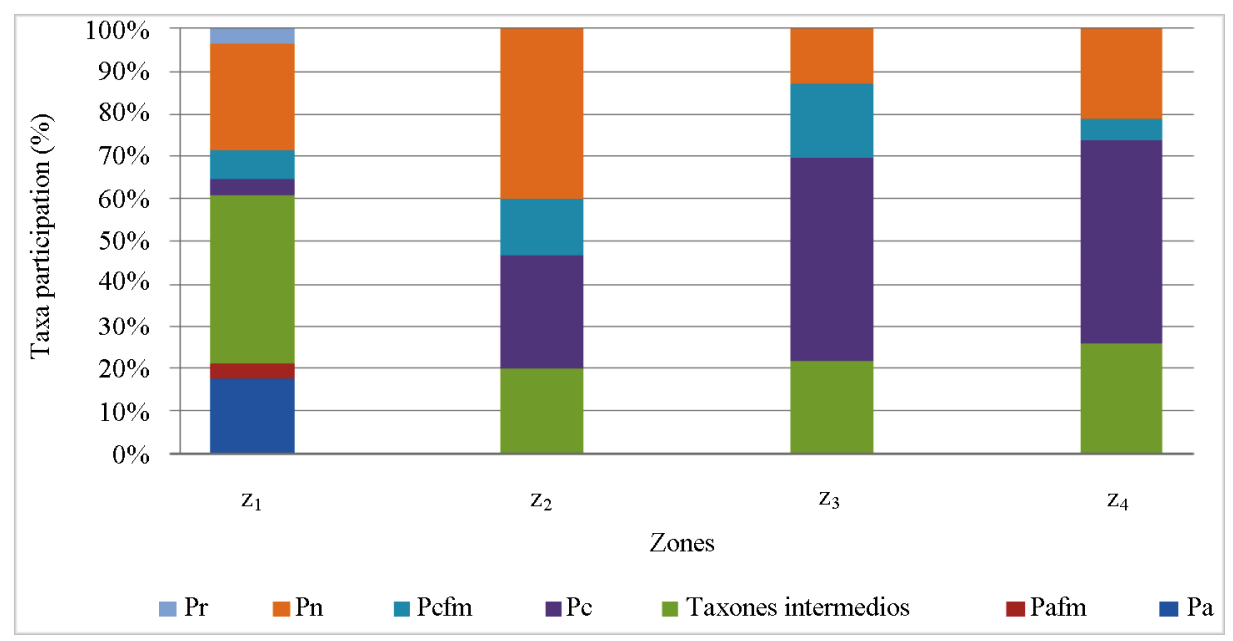

Figure 3. Participation percentage of each taxon in the sample by zone.
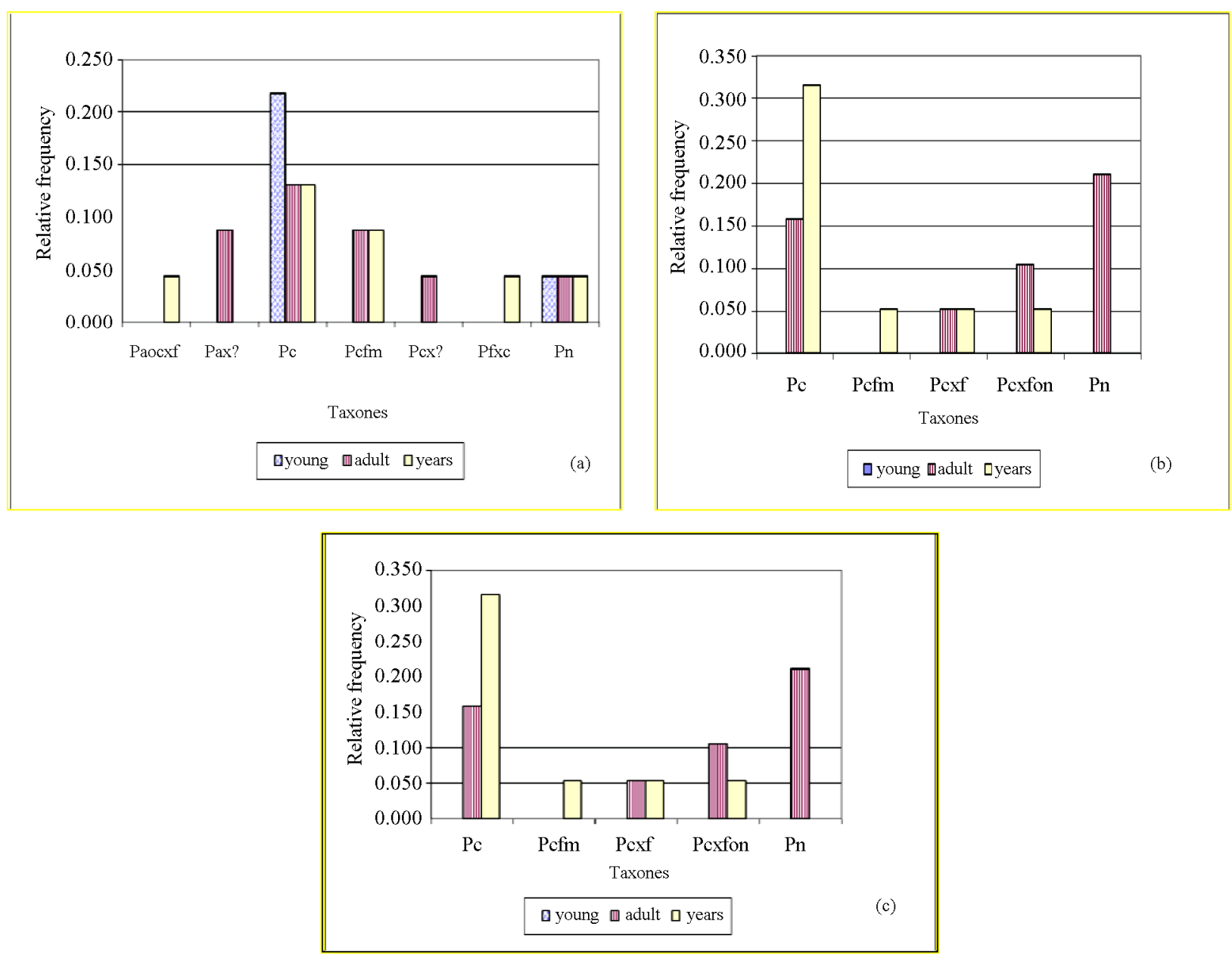

Figure 4. Distribution of relative frequencies of taxa according to age present in: (a) $Z_{2}$, (b) $Z_{3}$ and (c) $Z_{4}$.

merical taxonomy, was carried out at the level of mother plants harvested field and level of offspring of these plant mothers.

\subsubsection{Mother Plants}

The branches and fruit collected during the harvest were herborized and a total of 19 morphological characters for 
each tree were analyzed.

\subsubsection{Leaf Characters}

10 leaves from two sampled branches were taken into account providing the following characteristics (Figure 5):

Length of petiole (LPEC), length of pinnae (LPIN), length of leaflet (LFOL) and separation between leaflets (SFOL): $\mathrm{mm}$ with digital caliper.

Number of pairs of pinnae (NPIN) and number of pairs of leaflets for pinnae (NFOL): number.

Width of leaflet (AFOL): mm, magnifying glass graduated in tenths of $\mathrm{mm}$.

Calculation: the relationship length/width leaflets (L/AFOL). A total of 10 leaves by harvested tree were measured.

\subsubsection{Fruit Characters}

Were recorded the following characters were obtained from 10 fruits taken from each mother plant (Figure 5):

Length of fruit (LFR). A graduated cable was extended on each fruit in order to measure the length in $\mathrm{cm}$.

Width of fruit (AFR). It was measured in $\mathrm{mm}$ on the middle region of the fruit using a digital caliper.

Thickness of fruit (EFR). It was measured in $\mathrm{mm}$ with a digital caliper on a central knuckle that had a seed.

Number of knuckles (NART). The number of knuckles per fruit was counted.
Reference: Sinuosity of the branch (SRAMA), Spinosity (ESPINA), Length of petiole (LPEC). Length of pinnae (LPIN). Length of leaflet (LFOL). Width of leaflet (AFOL). Separation between leaflet (SFOL). Length of fruit (LFR). Width of fruit (AFR). Thickness of fruit (EFR). Edge of fruit: 4.- rosary form (BORDE: 4). Fruit shape: 3: spiraled (FORMA).

For the following variables of fruit a qualitative scale was established (classes) as used by Verga [11]:

Fruit colour, with classes (COLOR): 1) uniform yellow; 2) yellow background with purple spots (mainly edges), 3) preponderates purple or black on yellow appears with a very blocked or smeared.

Edge of fruit, with classes (BORDE): 1) Straight, 2) some chokes, 3) strangulated on all knuckles, 4) rosary form.

Fruit shape, with classes (FORMA): 1) straight, 2) falcate, 3) spiraled.

The relationship between length/number of knuckles (L/NART) and the width/thickness (A/EFR) were also included as characteristics of the fruit.

Branch characters: classes were established to qualify the character of a degree from lowest to highest intensity (Figure 5).

Sinuosity of the branch, with classes (SRAM): 1) straight, 2) winding, 3) very winding.

Spinosity, classes (ESPINA): 1) boneless, 2) spiny, 3) very thorny.

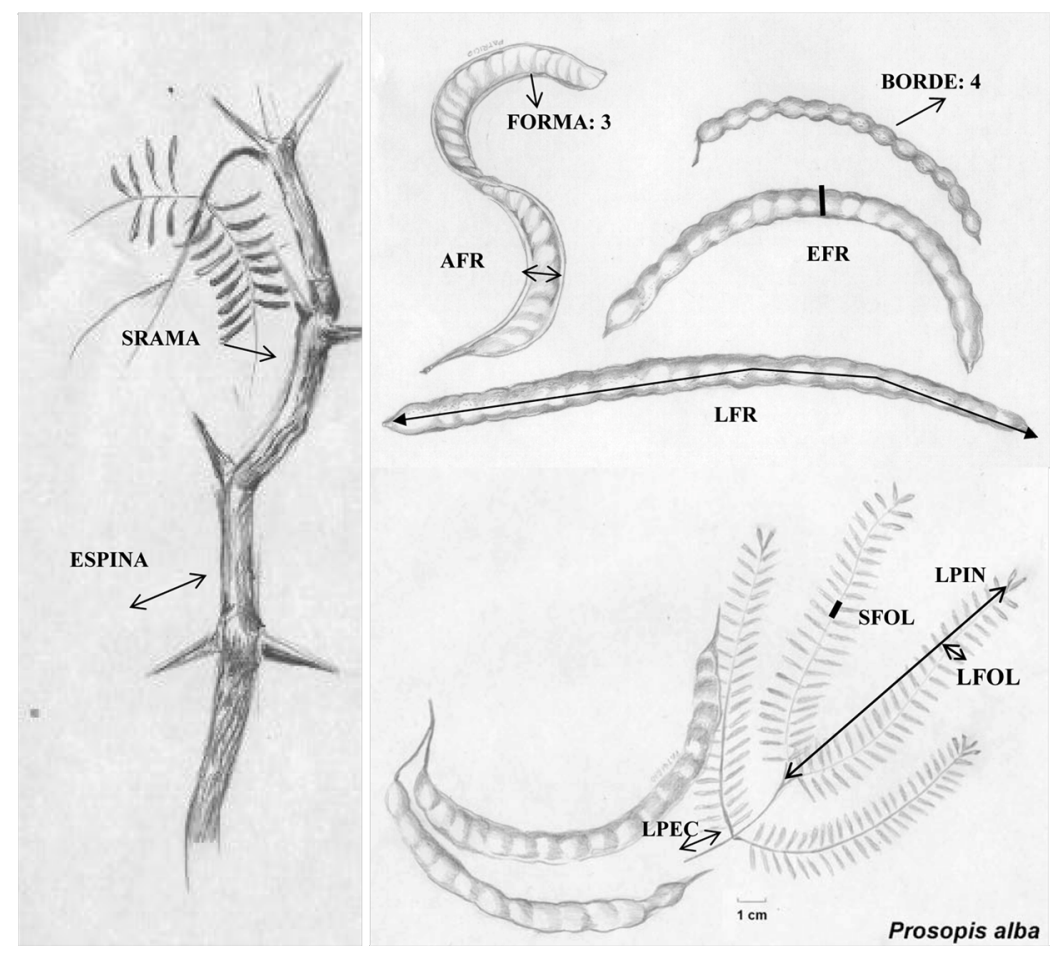

Figure 5. Illustration of the characters of leaf, fruit and branch in the mother plants. 


\subsubsection{The Offspring}

For the morphological study of mother plants offsprings a trial in the nursery of Facultad de Ciencias Agropecuarias in November 2000 was established. Seedlings were produced by direct seeding (seed scarified and soaked in water at room temperature for 10 hours), in bottomless tube packages of $6 \mathrm{~cm}$ diameter $\times 20 \mathrm{~cm}$ long. This trial served to address two different aspects: 1) record variables of growth and form on each seedling and 2) the morphological analysis.

Thus, for each seedling the height at four seedling ages was measured: $39\left(\mathrm{ALT}_{1}\right), 55\left(\mathrm{ALT}_{2}\right), 118\left(\mathrm{ALT}_{3}\right)$ and $168\left(\mathrm{ALT}_{4}\right)$ days after sowing. The main stem and the degree of spinosad after 180 days of the seedling were also recorded.

Three levels were established for the variable shape of the main stem (TALLO): 1) straight, 2) winding and 3) very winding and three for the degree of spinosity (ESPINA): 1) boneless, 2) moderately thorny, 3) very thorny.

10 seedlings per family were chosen at random and a well developed leaf was taken from each one to do the morphological analysis.

The following characteristics resulted from measuring with digital caliper: Number of pinnae (NPIN), Number of pairs of leaflets for pinnae (NFOL); Length of leaflet (LFOL), Length of pinnae (LPIN), Separation between leaflet (SFOL), and calculated with the HOJAS programme [45]: Length of leaflet (LFOL), Width of leaflet (AFOL), ratio length/width leaflet (L/AFOL), falcate of leaflet (FALCA), area of leaflet (ARFOL), ratio apex with total (AP/TOT) and apex of leaflet (APICE).

\subsection{Morphological Relationships between Mother Plants and Offspring}

The association between the morphological groups of harvested trees and their descendents was studied using cannonical correlation analysis (CCA) between the group of morphological variables of mothers and the group of variables to their descendents, verifying their statistical significance. This analysis was conducted for each morphological group.

\subsection{Statistical Analysis}

\subsubsection{Morphological Analysis}

This analysis was done to determine the morphological distances $\left(d_{m}\right)[12,13]$ from morphological characters. To calculate $d_{m}$ Taxon software [46] was used. The matrix used for the calculation of morphological distances $d_{m}$ was dimension $79 \times 19$ for the number of trees and morphological characters respectively.

\subsubsection{Cluster Analysis}

For the formation of the morphological groups in the mother plants morphological distance $d_{m}$ was used and they were grouped according to the UPGMA clustering method. Cluster analysis on the program NTSYS [47] was carried out in order to see if it met the same clusters in the offspring. It was considered that each offspring belonged to same group of the parent plant.

\subsubsection{Of Mother Plants}

Of the 85 harvested plants 6 trees had to be rejected (Trees $\mathrm{N}^{\circ}$ : 18-25-27-28-47) for the morphological analysis because of lack of sufficient material. So, 79 mother plants were analyzed morphologically in order to assess the value of the characters for the morphological differentiation and the formation of the groups. The total differentiation of the characters $\left(\delta_{T}\right)$ and R correlation coefficients between the matrix of average morphological distance between groups and each emerging one to each character were calculated.

\subsubsection{Of the Offspring}

A completely randomized design with 6 replications of 5 plants $\times 78$ mother plants was used.

\subsubsection{Discriminant Analysis}

To identify the homogeneity of the morphological groups formed in both mothers and in offspring, a quadratic discriminant analysis was done. To select the variables the Stepwise method [48] was used. The program used for this analysis was the SAS [49].

\subsubsection{Morphological Relationships between Mothers and Offspring Plants}

Relationships between morphological variables of mothers and offspring could be established by means of multivariate canonical correlation analysis (CCA) [50]. This analysis is used to establish the linear relationship between two groups of metric variables, some independent and others considered as dependents. That is, the CCA addressed the association between two sets or groups of variables, identifying and quantifying the association. The program used for this analysis was the InfoStat [51].

\section{Results}

\subsection{Morphological Analysis}

\subsubsection{Mother Plants}

Figure 6 shows that at the level of $78 \%$ two groups differentiated. From the tree 1 to 52 , corresponding to the group of "white" and from 3 to 85 representing the "black".

Within each of these two groups, clearly sub-groups 


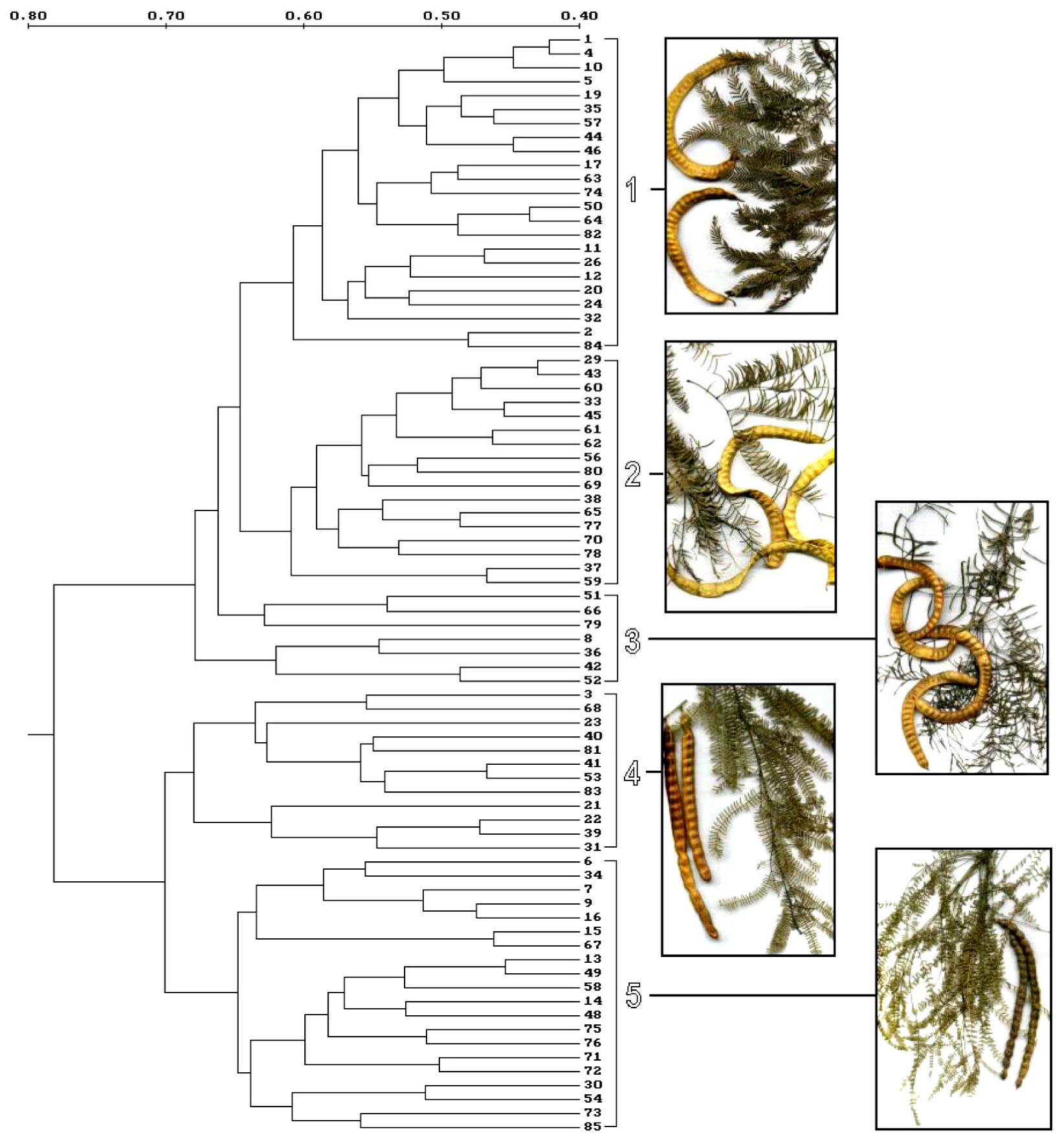

Figure 6. Dendrogram obtained by UPGMA method based on morphological distance between individuals represented by all the morphological characters of the mother plants.

were formed, which in some cases may correspond to differences among species or the presence of intermediate individuals. At level of $70 \%$ the formation of 5 groups is observed (Figure 6).

Comparing these groups with the determinations made in the Laboratory of Vascular Plants of the University of Buenos Aires following the classical taxonomy, group 1 consists of individuals classified as $P$. alba, $P$. chilensis,
P. chilensis with leaflets smaller and hybrids between two species, group 2 is formed by individuals classified mainly as $P$. chilensis and group 3 corresponds to $P$. chilensis and three individuals hybrids between this species and P. alba. Group 4 is totally intermediate formed by different types of hybrids (white by black carob or vice versa) and group 5 consists mainly of $P$. nigra (Table 3). 

Chaco of Northern Cordoba and Southern Santiago Del Estero

Table 4 presents the average values of fruit and leaf characters for each group and their respective coeffi- cients of variation (in\%) and in Table 5, the values found for $\delta_{T}$ and R.

Table 3. Morphological composition of each group by number of tree, zone and classification according to classical taxonomy.

\begin{tabular}{|c|c|c|}
\hline Groups & Zone and Accession & Number of individuals \\
\hline 1 & $\begin{array}{l}Z_{1}=1-4-5-24(\mathbf{P c x a}), 2(\mathrm{Pax} ?), 10-17-32\left(\mathrm{Pc}_{\mathrm{fm}}\right), 11-12-20-26(\mathrm{~Pa}), 19(\mathrm{Pc}), \\
\mathrm{Z}_{2}=35-50(\mathrm{Pc}) . \mathrm{Z}_{3}=44-46-63-64(\mathrm{Pc}), 57\left(\mathrm{Pc}_{\mathrm{fm}}\right) . \mathrm{Z}_{4}=84(\mathrm{~Pa}), 74-82(\mathrm{Pc}) .\end{array}$ & 23 \\
\hline 2 & $\begin{array}{c}\mathrm{Z}_{2}=29(\mathrm{~s} / \text { ident }), 33\left(\mathrm{Pc}_{\mathrm{fm}}\right), 37(\mathrm{Pc}) \cdot \mathrm{Z}_{3}=43-56-59-60-61-62(\mathrm{Pc}) \\
38-45\left(\mathrm{Pc}_{\mathrm{fm}}\right) \cdot \mathrm{Z}_{4}=78\left(\mathrm{Pc}_{\mathrm{fm}}\right), 65-69-70-77-80(\mathrm{Pc})\end{array}$ & 17 \\
\hline 3 & $\begin{array}{c}Z_{1}=8 \text { (Pcxa). } Z_{2}=36 \text { (Pcxa), } 51(\mathrm{Pc}) \\
Z_{3}=42\left(\mathrm{Pc}_{\mathrm{fm}}\right), 52 \text { (Pax?). } Z_{4}=66-79(\mathrm{Pc})\end{array}$ & 7 \\
\hline 4 & $\begin{array}{c}\left.Z_{1}=3 \text { (Pf o Pfxa)-21 (Pcxr)-22 (Paxn)-23 (Pa } \text { ffm }\right) \cdot Z_{2}=31(\text { Pax }) . \\
Z_{3}=39 \text { (Pax)-40 (Pcx?)-41 (Paxf)-53 (Pfxc). } Z_{4}=68 \text { (Pfxc)-81 (Pcxf)-83 (Pcxf). }\end{array}$ & 12 \\
\hline 5 & $\begin{array}{c}Z_{1}=\mathbf{6} \text { (Pf o Pfxa), 7-9-13-14-15-16-85(Pn). } Z_{2}=30-34-49-54(\mathrm{Pn}) \\
Z_{3}=48-58(\mathrm{Pn}) . Z_{4}=67-71-72-73(\mathrm{Pn}), 75-76 \text { (Pcxfon). }\end{array}$ & 20 \\
\hline Total & & 79 \\
\hline
\end{tabular}

Reference: in bold, individuals with intermediate characteristics according to the classification of Vascular Plants Laboratory at the University of Buenos Aires (hybrids).

Table 4. Average and coefficients of variation (CV) in percentage, by character and group.

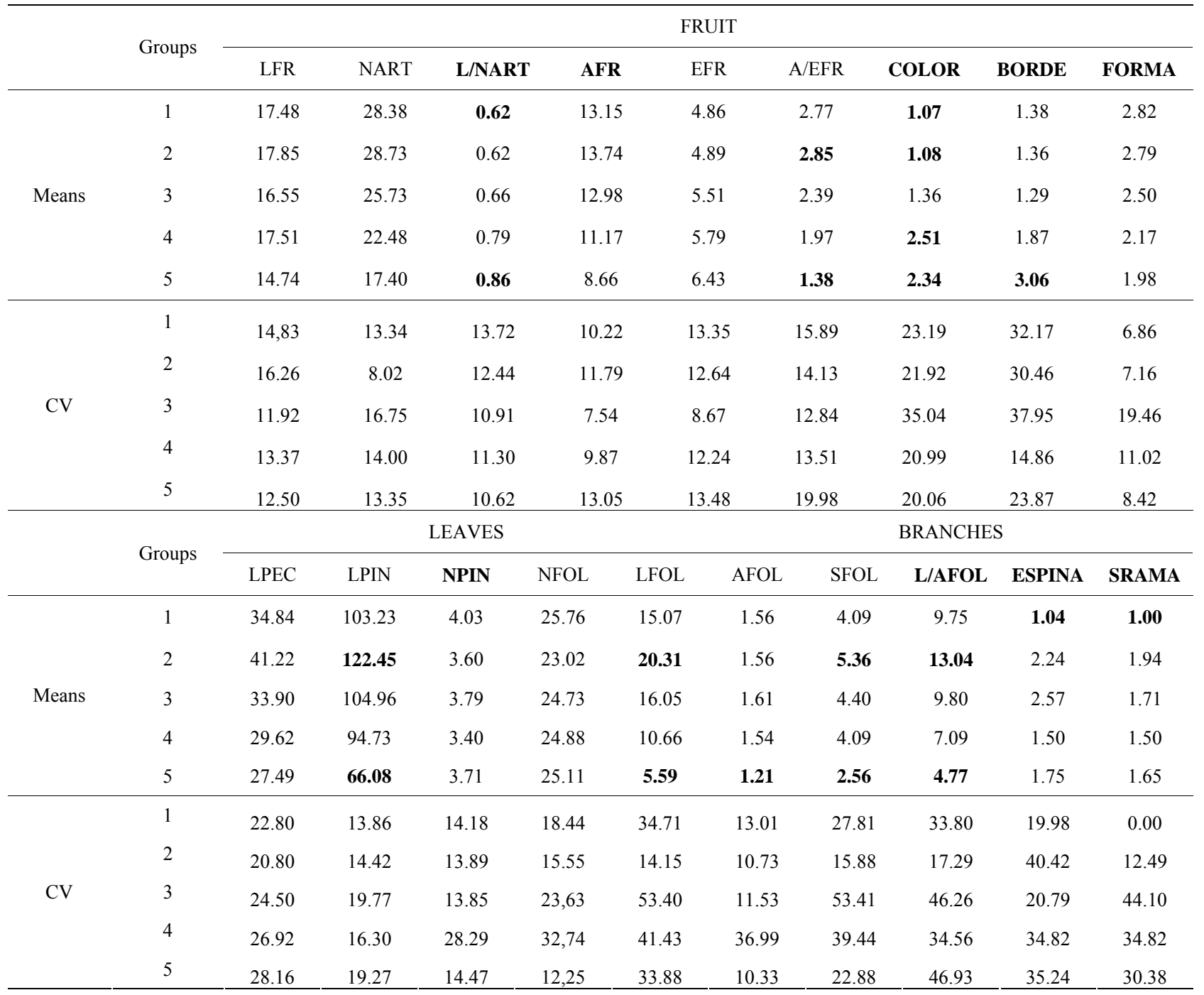

Reference: Variables in bold are the variables that were selected to perform the discriminant analysis. CV: coefficient of variation. 
Table 5. Total differentiation of the characters $\left(\delta_{T}\right)$ and correlation coefficient $(\mathrm{R})$ between the matrices of average morphological distance between groups and each one of the emerging ones for each character.

\begin{tabular}{|c|c|c|c|c|c|c|c|c|c|}
\hline \multicolumn{10}{|c|}{ Leaf characters } \\
\hline & L/AFOL & LFOL & SFOL & LPIN & NFOL & AFOL & LPEC & NPIN & \\
\hline$\delta_{T}$ & 0.893 & 0.889 & 0.820 & 0.767 & 0.748 & 0.723 & 0.636 & 0.320 & \\
\hline$R$ & 0.773 & 0.847 & 0.600 & 0.780 & -0.389 & 0.817 & 0.590 & -0.150 & \\
\hline \multicolumn{10}{|c|}{ Fruit characters } \\
\hline & $\mathrm{A} / \mathrm{EFR}$ & AFR & L/NART & NART & EFR & LFR & BORDE & COLOR & FORMA \\
\hline$\delta_{T}$ & 0.857 & 0.843 & 0.809 & 0.787 & 0.782 & 0.699 & 0.654 & 0.601 & 0.470 \\
\hline \multirow[t]{3}{*}{$R$} & 0.955 & 0.886 & 0.960 & 0.990 & 0.900 & 0.399 & 0.816 & 0.860 & 0.892 \\
\hline & \multicolumn{9}{|c|}{ Branch characters } \\
\hline & ESPINA & SRAMA & & & & & & & \\
\hline$\delta_{T}$ & 0.623 & 0.519 & & & & & & & \\
\hline$R$ & -0.148 & -0.337 & & & & & & & \\
\hline & TOTAL & & & & & & & & \\
\hline$\delta_{T}$ & 0.689 & & & & & & & & \\
\hline
\end{tabular}

Reference: The $R$ in bold represents significant values $(\mathrm{P}<0.05)$ and variables in bold correspond to variables selected by Stepwise method.

The variables, which were subsequently selected for the discriminant analysis, were the variables in bold. Most were qualitative ordinals (ESPINA, SRAMA, COLOR, BORDE Y FORMA), only three were quantitative variables (NPIN, L/NART, AFR and L/AFOL). In Table 4, it can be seen how the character of fruit color in the morphological groups was distributed. Groups 1, 2 and 3 had white fruits (values close to 1) while groups 4 and 5 had darker fruit (values greater than 2). The gradation in color coincided with the ordering of the morphological groups. In general it can also be noted that groups 3 and 4 showed intermediate values for most characters, between groups 1 and 2 per side, and 5 on the other hand, as extreme.

For those variables that were selected by the stepwise method, the total differentiation of the characters $\left(\delta_{T}\right)$ was higher than 0.519, except for NPIN and FORMA, which showed lower values. It should be noted that values close to 1 imply a greater degree of differentiation provided by the character.

For the variables mentioned in the preceding paragraph, it is observed that with the exception of variables ESPINA, SRAMA and NPIN, the rest presented significantly high correlation with the distance matrix of average morphological differentiation (Table 5).

\subsubsection{Discriminant Analysis}

Of a total of 19 variables 9 were selected using the Stepw method (COLOR, AFR, SRAMA, FORMA, ESPINA, BORDE, L/NART, LAFOL and NPIN).

Fruit color was the first to contribute to group differentiation, followed by the width of the fruit and the sinu- osity of the branch. These three characters had a partial $\mathrm{R}^{2}$ high $(0.747,0.51$ and 0.442$)$. Of these variables only color and width of fruit showed relatively high values of $\mathrm{R}$ and $\delta_{T}$, while the sinuosity of branch showed an intermediate $\delta_{T}$ (Table 5).

Fruit and branch characters were those which have had greater participation in the formation of the groups. Table 6 shows the classification results, with an error rate of $24 \%$, meaning that the correct assignment to this cluster structure is $76 \%$. The groups that most influence had on the rate of error were 3 and 4, due to the intermediate characteristics of the individuals who compose them and their high morphological diversity, whereas in the other groups the degree of confusion was very low.

\subsection{Discriminant Analysis for Character of Offspring Sheet}

It has been examined whether the offspring was due to clusters in the mother plants obtained by discriminant analysis.

Since there was not enough data, two assessments were made: one for leaf morphology variables and one for variables included directly in the nursery: height at different times, stem form and degree of thorns.

\subsubsection{Discriminant Analysis for Character of Sheet}

The method of Stepwise variable selection chose 8 of the 12 variables analyzed: LFOL, NPIN, ARFOL, AFOL, FALCA, LPIN, APICE, L/AFOL.

To determine whether there was homogeneity of covariance between groups the modified Bartlett test was applied. This test gave significant at $0.1 \%$. This means 
that there is no homogeneity between groups covariance so it was necessary to perform a quadratic discriminant analysis.

The total error rate of this analysis was very high showing that it is not possible to group the progeny and the mother plants in the same way (Table 7).

Thus, of the offspring of 23 mother plants belonging to group 1, a large percentage confused with group 2 (41\%) and $4(20 \%)$ and only $32 \%$ are in the group.

In the progeny of 17 individuals forming group 2, there is a high percentage remaining in the same group $(70 \%)$. Most of the remaining $30 \%$ is confused with group $1(10 \%)$ and $5(12 \%)$.

As for group 3, intermediate group with respect to the average value of their characters, there is no individual in that group.

In group $4,18 \%$ of the individuals which forms it fo- cuses in greater proportion on group $5(53 \%)$ and 2 $(20 \%)$.

Finally, the descendants of group 5 are grouped by $85 \%$, thus becoming the most stable group for these variables.

\subsubsection{Discriminant Analysis for Variables Recorded in the Nursery}

Of a total of 6 variables, Stepwise method selected 5 (Table 8), leaving aside the degree of thorniness.

As for leaf characters that were discussed above, quadratic discriminant analysis was used, because there was no homogeneity among the matrices covariance.

The error rate, considering these variables, also remains high (0.5947). Thus, the offspring of the mother plants belonging to group 1, a percentage of $58 \%$ fall in group 1 and $32 \%$ in group 5 (Table 8).

Table 6. Percent of individuals belonging to each group and error rate for the groups formed.

\begin{tabular}{|c|c|c|c|c|c|c|c|}
\hline \multirow{2}{*}{\multicolumn{2}{|c|}{ Real group }} & \multicolumn{6}{|c|}{ Predicted group } \\
\hline & & \multirow{2}{*}{$\begin{array}{c}1 \\
95.65\end{array}$} & \multirow{2}{*}{$\begin{array}{c}2 \\
4.35\end{array}$} & \multirow{2}{*}{$\begin{array}{c}3 \\
0.00\end{array}$} & \multirow{2}{*}{$\begin{array}{c}4 \\
0.00\end{array}$} & \multirow{2}{*}{$\frac{5}{0.00}$} & \multirow{2}{*}{$\begin{array}{c}\text { Total } \\
100\end{array}$} \\
\hline 1 & $\%$ & & & & & & \\
\hline 2 & $\%$ & 0.00 & 94.12 & 0.00 & 0.00 & 5.88 & 100 \\
\hline 3 & $\%$ & 28.57 & 28.57 & 0.00 & 0.00 & 42.86 & 100 \\
\hline 4 & $\%$ & 8.33 & 0.00 & 0.00 & 41.67 & 50.00 & 100 \\
\hline 5 & $\%$ & 0.00 & 0.00 & 0.00 & 15.00 & 85.00 & 100 \\
\hline \multirow[t]{3}{*}{ Total } & $\%$ & 31.65 & 24.05 & 0.00 & 10.13 & 34.18 & 100 \\
\hline & \multicolumn{7}{|c|}{ Jacknife error rate for formed groups } \\
\hline & & 1 & 2 & 3 & 4 & 5 & Total \\
\hline \multicolumn{2}{|c|}{ Rate } & 0.0435 & 0.0588 & 1.0000 & 0.5833 & 0.1500 & 0.2405 \\
\hline \multicolumn{2}{|c|}{ Priors } & 0.2911 & 0.2151 & 0.0886 & 0.1519 & 0.2531 & \\
\hline
\end{tabular}

Table 7. Percentage of individuals assigned by groups and error rate for the groups formed.

\begin{tabular}{|c|c|c|c|c|c|c|c|}
\hline \multirow{2}{*}{\multicolumn{2}{|c|}{ Real group }} & \multicolumn{6}{|c|}{ Predicted group } \\
\hline & & \multirow{2}{*}{$\begin{array}{c}1 \\
32.17\end{array}$} & \multirow{2}{*}{$\begin{array}{c}2 \\
40.87\end{array}$} & \multirow{2}{*}{$\frac{3}{1.30}$} & \multirow{2}{*}{$\begin{array}{c}4 \\
5.65\end{array}$} & \multirow{2}{*}{$\begin{array}{c}5 \\
20.00\end{array}$} & \multirow{2}{*}{$\begin{array}{c}\text { Total } \\
100\end{array}$} \\
\hline 1 & $\%$ & & & & & & \\
\hline 2 & $\%$ & 10.59 & 69.41 & 1.76 & 6.47 & 11.76 & 100 \\
\hline 3 & $\%$ & 12.86 & 38.57 & 0.00 & 11.43 & 37.14 & 100 \\
\hline 4 & $\%$ & 5.83 & 20.00 & 2.50 & 18.33 & 53.33 & 100 \\
\hline 5 & $\%$ & 2.15 & 6.45 & 0.54 & 3.23 & 84.63 & 100 \\
\hline \multirow[t]{3}{*}{ Total } & $\%$ & 14.43 & 35.44 & 1.29 & 7.73 & 41.11 & 100 \\
\hline & \multicolumn{7}{|c|}{ Jacknife error rate for formed groups } \\
\hline & & 1 & 2 & 3 & 4 & 5 & Total \\
\hline \multicolumn{2}{|c|}{ Rate } & 0.6783 & 0.3059 & 1.0000 & 0.8167 & 0.1237 & 0.5142 \\
\hline \multicolumn{2}{|c|}{ Priors } & 0.2964 & 0.2191 & 0.0902 & 0.1546 & 0.2397 & \\
\hline
\end{tabular}


Table 8. Percentage of individuals assigned by groups and error rate for the groups formed.

\begin{tabular}{|c|c|c|c|c|c|c|c|}
\hline \multirow{2}{*}{\multicolumn{2}{|c|}{ Real group }} & \multicolumn{6}{|c|}{ Predicted group } \\
\hline & & \multirow{2}{*}{$\begin{array}{c}1 \\
\mathbf{5 7 . 5 0}\end{array}$} & \multirow{2}{*}{$\begin{array}{c}2 \\
6.64\end{array}$} & \multirow{2}{*}{$\frac{3}{3.04}$} & \multirow{2}{*}{$\begin{array}{c}4 \\
0.95\end{array}$} & \multirow{2}{*}{$\begin{array}{c}5 \\
31.88\end{array}$} & \multirow{2}{*}{$\begin{array}{c}\text { Total } \\
100\end{array}$} \\
\hline 1 & $\%$ & & & & & & \\
\hline 2 & $\%$ & 39.73 & 9.07 & 5.07 & 0.53 & 45.60 & 100 \\
\hline 3 & $\%$ & 36.31 & 10.12 & 7.74 & 1.79 & 44.05 & 100 \\
\hline 4 & $\%$ & 37.75 & 8.43 & 2.81 & 2.01 & 49.00 & 100 \\
\hline 5 & $\%$ & 14.55 & 2.73 & 0.91 & 0.45 & 81.36 & 100 \\
\hline \multirow[t]{3}{*}{ Total } & $\%$ & 14.43 & 35.44 & 1.29 & 7.73 & 41.11 & 100 \\
\hline & \multicolumn{7}{|c|}{ Jacknife error rate for formed groups } \\
\hline & & 1 & 2 & 3 & 4 & 5 & Total \\
\hline \multicolumn{2}{|c|}{ Rate } & 0.4250 & 0.9093 & 0.9226 & 0.9799 & 0.1864 & 0.5947 \\
\hline \multicolumn{2}{|c|}{ Priors } & 0.2996 & 0.2132 & 0.0955 & 0.1416 & 0.2501 & \\
\hline
\end{tabular}

This behaviour is also observed in the offspring of the individuals in group 2, 3 and 4, which give individuals, which secrete primarily in groups 1 and 5 .

The behaviour of the offspring of group 5 was different, focusing on the same group (81\%) and slightly on group $1(14 \%)$.

To summarize, it is fair to clarify that it was difficult to bring together the descendants under the grouping of the mother plants considering these characters, since there is a high error rate.

The error of morphological leaf variables was provided with in a higher percentage by groups 1,3 and 4, while for the growth variables the groups that contributed more error were 2, 3 and 4 .

Table 9 shows the average and coefficients of variation for character and group for the variables studied in the offspring.

The graphs of these measured variables on offspring ordered by morphological group from the mother plants show that despite the high degree of error found, some of these variables allow groups to differentiate. Thus, the length of leaflet in offspring of group 5 is of the lowest value, while for the group of $P$. chilensis (group 2) is of greater value.

Other interesting variables are the ratio of width to length of leaflet and apex shape. The L/AFOL is also greater in group 2 and then decreases towards the other groups. As for the shape of the apex in group 5, it is more rounded than the other groups that tend to be more acute.

\subsection{Distribution of Morphological Groups by Area}

Noting the distribution of morphological groups by zones, $Z_{1}$ (Santiago del Estero) is the most different; since the morphological group 2 (P. chilensis) is absent. The remaining areas (Córdoba) have the 5 morphological groups but in different proportions (Figure 7).

\subsection{Study of the Association between Characters of Seed Trees and Their Offspring}

The relationship between the morphological groups of harvested trees and offspring, as measured by canonical correlation analysis, was conducted among a group of mother's morphological variables (with the exception of type of branch) and the variable group of offspring for each morphological group.

Although the data are presented together, each morphological group had a canonical correlation analysis independent from the other groups.

Most of the morphological groups needed two pairs of canonical variables (L) to establish association between variables groups of mothers and offspring, except for group 3 in which this association was well defined with only one canonical correlation (Table 10).

Even though all groups had a highly significant canonical correlation, the groups 3 and 4 were highlighted presenting the highest values of $\mathrm{R}^{2}$ (Table 10). This correlation indicates that the variability found in mothers is strongly associated with the variability found in offspring, in other words, the observed variability in both sets follows a certain order or relationship between pairs of sets of variables.

Note that the linear combinations with correlation maximum for each pair (L) and for each morphological group were formed with different associations of variables for both the first set (morphological variables of mothers) with the second set (morphological variables of the offspring ).

Thus, it can be said that in the mothers set (Table 11), for groups 1 and 2, morphological characters of fruit had more weight than the characters of leaves, while for the other groups involving both types of characters was eq- 
Table 9. Average and coefficients of variation of offspring by character and group.

\begin{tabular}{|c|c|c|c|c|c|c|c|c|c|c|}
\hline & \multirow{2}{*}{ Groups } & \multicolumn{9}{|c|}{ CHARACTERS } \\
\hline & & LPEC & LPIN & NPIN & NFOL & SFOL & LFOL & AFOL & L/AFOL & FALCA \\
\hline \multirow{5}{*}{ Means } & 1 & 10.40 & 50.05 & 2.57 & 28.92 & 1.66 & 0.61 & 0.14 & 4.42 & 0.95 \\
\hline & 2 & 11.25 & 50.32 & 2.45 & 25.51 & 1.85 & 0.70 & 0.14 & 5.01 & 0.95 \\
\hline & 3 & 9.66 & 44.65 & 2.47 & 23.67 & 1.78 & 0.61 & 0.14 & 4.32 & 0.95 \\
\hline & 4 & 8.58 & 38.75 & 2.25 & 21.78 & 1.70 & 0.48 & 0.13 & 3.84 & 0.95 \\
\hline & 5 & 7.62 & 32.02 & 2.33 & 20.08 & 1.45 & 0.36 & 0.11 & 3.41 & 0.95 \\
\hline \multirow{7}{*}{$\mathrm{CV}$} & 1 & 16.49 & 11.21 & 15.77 & 14.84 & 20.19 & 16.80 & 10.01 & 11.68 & 1.45 \\
\hline & 2 & 19.59 & 15.34 & 12.10 & 15.22 & 10.96 & 16.03 & 11.57 & 8.87 & 0.98 \\
\hline & 3 & 29.10 & 16.88 & 10.11 & 7.24 & 11.17 & 31.68 & 21.82 & 17.20 & 2.68 \\
\hline & 4 & 22.61 & 14.67 & 9.38 & 14.72 & 16.78 & 21.01 & 12.60 & 13.40 & 1.76 \\
\hline & 5 & 17.39 & 18.51 & 16.87 & 14.98 & 13.86 & 22.29 & 10.25 & 13.60 & 1.54 \\
\hline & Crin & \multicolumn{9}{|c|}{ CARACTERES } \\
\hline & & ARFOL & $\mathrm{AP} / \mathrm{TOT}$ & APICE & ALT1 & ALT2 & ALT3 & ALT4 & TALLO & ESPINA \\
\hline \multirow{5}{*}{ Means } & 1 & 0.07 & 0.20 & 0.94 & 6.58 & 16.03 & 32.43 & 36.28 & 1.81 & 1.65 \\
\hline & 2 & 0.08 & 0.20 & 0.92 & 7.18 & 16.46 & 32.97 & 36.14 & 2.07 & 2.05 \\
\hline & 3 & 0.08 & 0.21 & 0.99 & 6.97 & 15.95 & 31.32 & 34.84 & 2.16 & 2.23 \\
\hline & 4 & 0.05 & 0.21 & 0.99 & 6.62 & 14.44 & 28.17 & 31.85 & 1.84 & 1.90 \\
\hline & 5 & 0.03 & 0.23 & 1.08 & 6.31 & 12.49 & 24.96 & 28.09 & 2.16 & 2.23 \\
\hline \multirow{5}{*}{$\mathrm{CV}$} & 1 & 23.92 & 3.62 & 4.87 & 12.88 & 10.19 & 10.76 & 10.00 & 17.00 & 23.00 \\
\hline & 2 & 26.03 & 5.38 & 5.37 & 12.17 & 16.04 & 16.13 & 16.00 & 13.00 & 17.80 \\
\hline & 3 & 58.52 & 8.25 & 5.53 & 28.79 & 21.36 & 16.32 & 15.00 & 7.00 & 11.70 \\
\hline & 4 & 30.70 & 8.27 & 6.13 & 16.94 & 18.50 & 19.88 & 19.00 & 15.00 & 21.80 \\
\hline & 5 & 30.25 & 5.84 & 4.39 & 14.61 & 9.90 & 8.75 & 10.00 & 8.00 & 13.50 \\
\hline
\end{tabular}

uitable.

It is important to highlight that, when the associated characters between seed trees and offspring coincide in the distinct groups, this association keeps the same direction. Thus there is no evidence to indicate differences between groups in the form of association between traits studied.

The characters most involved in the linear combinations were NART, EFR, LFOL, L/AFOL in three of the five groups in the mother set, and LPIN and NFOL characters in the offspring set. In the latter group LFOL was distinguished, which appears in the five groups and it also was a variable selected by stepwise method to perform discriminant analysis.

Most of the characters involved in the associations have high values of coefficient of variation (Table 12).

The interpretation of these associations comes from analysing each pair of canonical variables. So for the Morphological group 1, the coefficients of linear combinations (Table 11) for the first partnership stated that: fruits with thick and ratio width/thickness considerable in mothers correlate significantly with offspring that had a ratio length/width of leaflet higher, associated inversely with the length of leaflet.

This would indicate, always in reference to the values recorded in this morphological group that mothers with large fruits in the dimensions of width and thickness tend to provide offspring with leaflet of the smallest dimension in length, but wide.

The second axis showed that mothers with less number of knuckles by fruit and with leaflet shorter in length were significantly associated with offspring which had longer pinnae but with fewer leaflet by pinnae.

Morphological group 2: For this group the first combination of canonical variables was associated significantly with greater fruit length and less number of knuckles in mothers with a greater length of the pinnae but with less number of leaflets in the offspring.

The second axis established that mothers with a greater presence of thorns and fruit thinner had offspring 


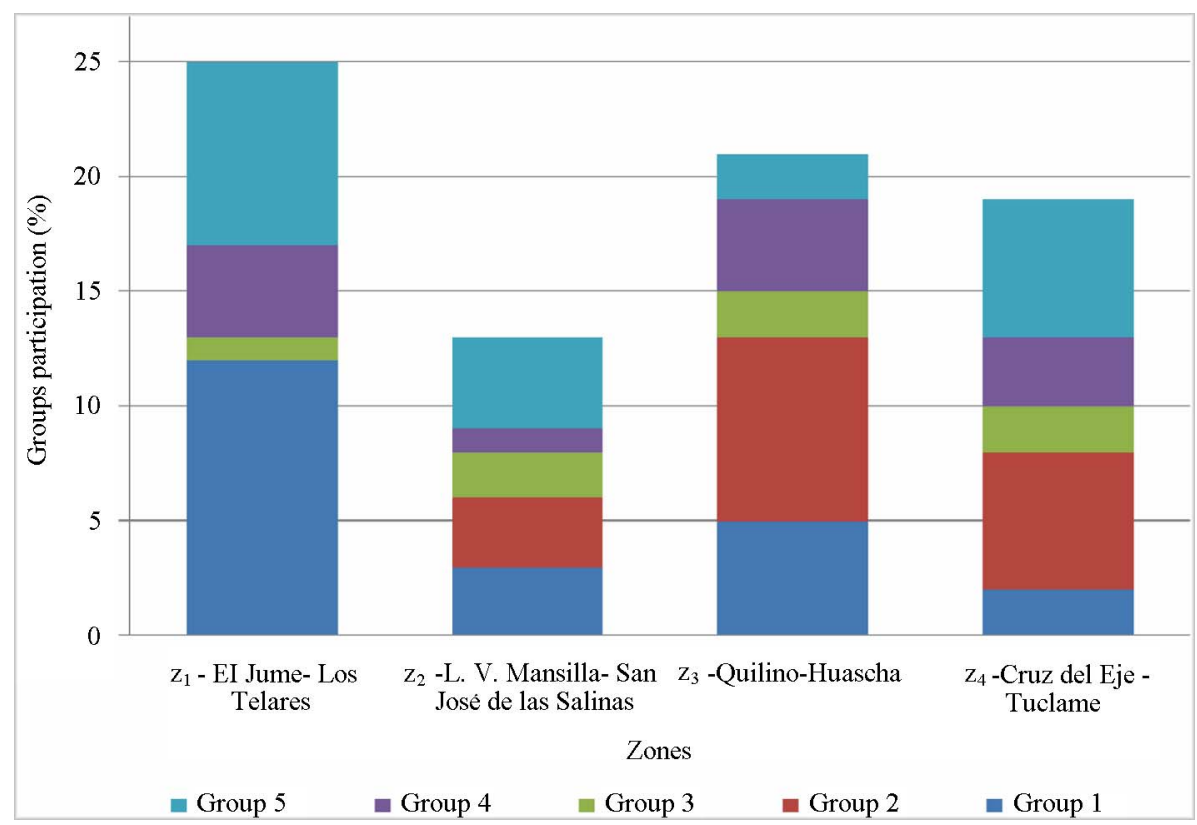

Figure 7. Distribution of morphological groups by area.

Table 10. Canonical correlation coefficients $(R)$, the proportion of total variance explained by each pair of canonical variables $\left(R^{2}\right)$ and associated probability levels (p-value) for each pair of canonical variables for each morphological group.

\begin{tabular}{|c|c|c|c|c|c|c|c|c|c|}
\hline \multirow{2}{*}{$\begin{array}{c}\text { Grupo } \\
\text { L }\end{array}$} & \multicolumn{2}{|c|}{1} & \multicolumn{2}{|c|}{2} & \multirow{2}{*}{$\begin{array}{l}3 \\
1\end{array}$} & \multicolumn{2}{|c|}{4} & \multicolumn{2}{|c|}{5} \\
\hline & 1 & 2 & 1 & 2 & & 1 & 2 & 1 & 2 \\
\hline $\mathrm{R}$ & 0.72 & 0.55 & 0.68 & 0.67 & 0.94 & 0.82 & 0.68 & 0.75 & 0.60 \\
\hline $\mathrm{R}^{2}$ & 0.51 & 0.30 & 0.46 & 0.45 & 0.89 & 0.67 & 0.46 & 0.57 & 0.37 \\
\hline p-valor ${ }^{*}$ & $1.4 \times 10^{-9}$ & $4.7 \times 10^{-3}$ & $7.4 \times 10^{-8}$ & $1.6 \times 10^{-4}$ & $5.3 \times 10^{-4}$ & $2.7 \times 10^{-7}$ & $3.7 \times 10^{-3}$ & $5.3 \times 10^{-10}$ & $1.5 \times 10^{-3}$ \\
\hline
\end{tabular}

${ }^{*}$ p-valor $<0.001$ is considered highly significant.

with major length in leaflet and growth in height of seedlings in the last measurement (168 days old).

In this group the importance for the character and the presence of thorns is emphasized. This has a high value of coefficient of variation and occurs only in this group.

In the case of morphological group $\mathbf{3}$ it was observed that the variability of the ratio length/width of leaflet and its inverse association with the ratio length/number of knuckles at the level of the mothers was significantly correlated with the pattern of inverse association that exists between length of leaflet and leaf area at the level of offspring.

It could be inferred for this group that leaves with leaflet of greater length than width, associated with a higher number of seeds by fruit in mothers (or seeds smaller for the same length of the fruit) will correspond with offspring which have leaflet longest but lower leaf area.

Morphological group 4: the canonical first axis presented the canonical variables: length of leaflet and ratio length/width of leaflet, associated inversely in set of mothers and significantly correlated with the length of leaflet which was, in turn, associated inversely with the number and spacing of leaflet by pinnae for set of offspring.

The second canonical axis showed that the thickness and the width/thickness of the fruit in mothers were correlated with the separation between leaflets associated inversely with height growth of seedlings in the fourth measurement date

It can be interpreted that mothers with long and wide leaflets tend to give offspring with long leaflet but with a fewer number of leaflet by pinnae and fewer separated. Also, mothers with fruits with the width dimension greater than the thickness will present offspring with less separation of leaflet and less growth in height to 168 days-old of seedling.

Morphological group 5: For this group the ratio width/thickness of the fruit associated with the ratio length/width of leaflet in mothers, correlated with the length of the pinnae and leaflet the offspring in the first canonical axis, while the second was found that the 
Table 11. Coefficients of linear combinations of canonical variables (L) for characters of mothers and offspring, for each morphological group. They indicate only the two largest absolute values for each group of variables.

\begin{tabular}{|c|c|c|c|c|c|c|c|c|c|c|c|}
\hline \multirow{3}{*}{ Set } & \multirow{2}{*}{\multicolumn{2}{|c|}{$\frac{\text { Group }}{\mathrm{L}}$}} & \multicolumn{2}{|c|}{1} & \multicolumn{2}{|c|}{2} & 3 & \multicolumn{2}{|c|}{4} & \multicolumn{2}{|c|}{5} \\
\hline & & & 1 & 2 & 1 & 2 & 1 & 1 & 2 & 1 & 2 \\
\hline & \multicolumn{2}{|c|}{ Character } & & & & & & & & & \\
\hline \multirow{9}{*}{ Mother } & \multirow{6}{*}{ Fruit } & LFR & & & 1.16 & & & & & & \\
\hline & & NART & & -1.90 & -0.96 & & & & & & -1.3 \\
\hline & & L/NART & & & & & -0.59 & & & & \\
\hline & & AFR & & & & & & & 1.52 & & \\
\hline & & EFR & 0.93 & & & -0.58 & & & -1.45 & & \\
\hline & & $\mathrm{A} / \mathrm{EFR}$ & 0.91 & & & & & & & 0.38 & \\
\hline & \multirow{3}{*}{ Leaf } & LFOL & & -1.74 & & & & 0.75 & & & -1.2 \\
\hline & & L/AFOL & & & & & 0.63 & -1.08 & & 0.43 & \\
\hline & & ESPINA & & & & 0.87 & & & & & \\
\hline \multirow{8}{*}{ Offspring } & \multirow{7}{*}{ Leaf } & LPIN & & 1.09 & 1.00 & & & & & 0.75 & \\
\hline & & NFOL & & -1.17 & -1.23 & & & -0.79 & & & \\
\hline & & SFOL & & & & & & & -0.93 & & \\
\hline & & LFOL & -2.41 & & & 1.66 & 1.19 & 0.87 & & 1.34 & \\
\hline & & AFOL & & & & & & & & & 1.57 \\
\hline & & L/AFOL & 0.87 & & & & & & & & 1.88 \\
\hline & & ARFOL & & & & & -0.67 & & & & \\
\hline & Growth & ALT4 & & & & 1.24 & & & -0.83 & & \\
\hline
\end{tabular}

Table 12. Coefficient of variation of the characters involved in the canonical correlation for the mothers and offspring set.

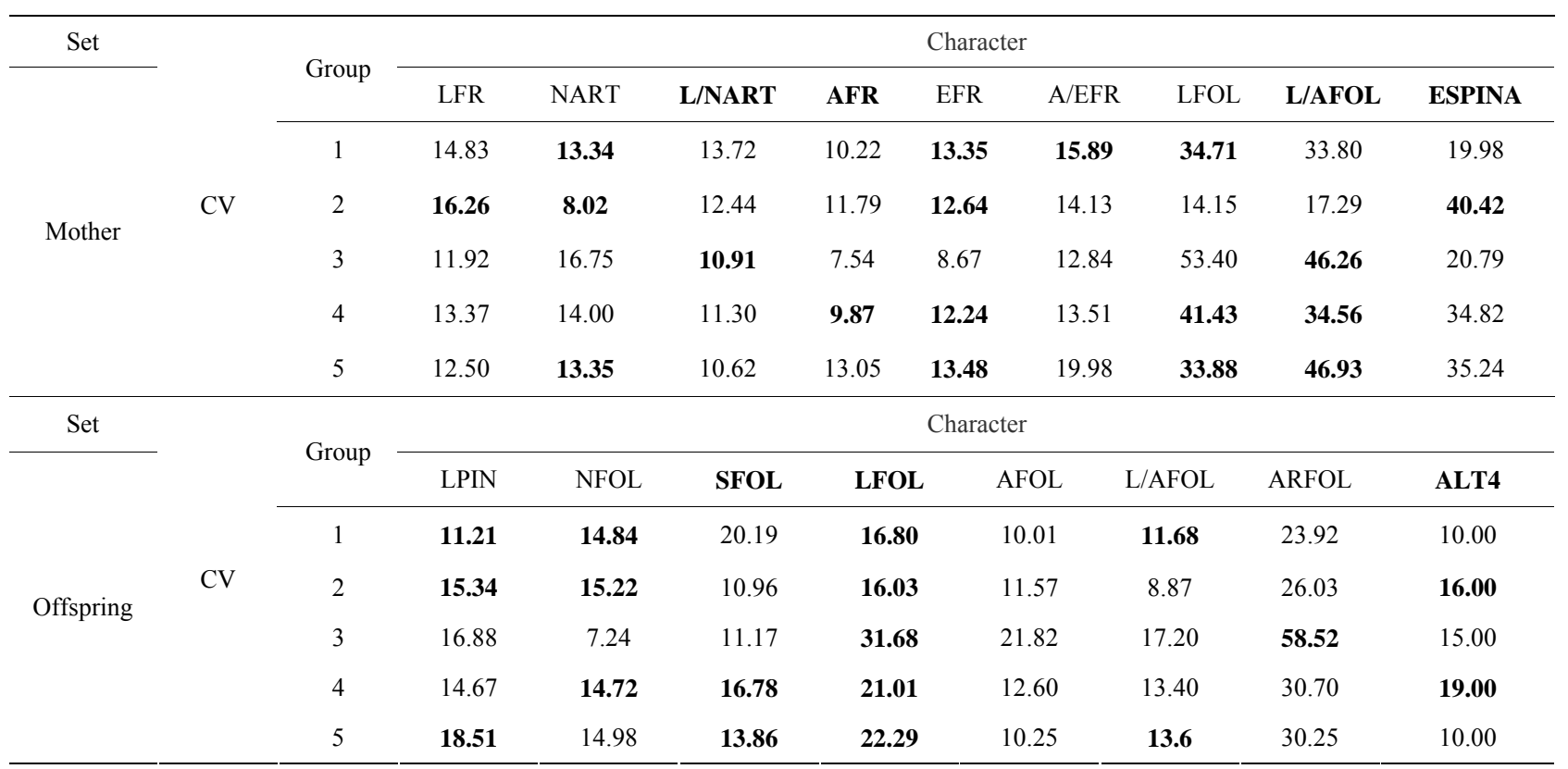

Reference: Variables in bold are the variables that were selected to perform the discriminant analysis and the numbers in bold indicate the variables that are part of the canonical axes.

number of knuckles and leaflet length inversely associ- ated with the length of the fruit in the mothers, was cor- 
related with the length of leaflet and inversely with the ratio length/width of leaflet in offspring.

Thus, mothers who have fruits with a greater dimension in width than in thickness and leaflet with more dimension in the long than in the width would give offspring with pinnae and longer leaflets.

\section{Discussion}

The use of numerical taxonomy is an essential tool for morphological analysis and proper identification of materials used in this study. Thus, a total of 19 variables used in this analysis were 9 the characters that contributed significantly to the construction of the morphological groups of mothers. These were mainly fruit characters (5) and branch (type of branch and thorns). The fruit characters of higher correlation with the discriminant functions estimated were the color and width of fruit. As for the character leaves, the ratio length/width of leaflet and the number of pair for pinnae were only considered.

Verga [11] found that characters ratio thickness/ width of fruit, ratio length/width of leaflet and length of leaflet were important for the differentiation of three morphological groups ( $P$. flexuosa, $P$. chilensis and hybrids) in the Chaco arid.

Also, Mantován [52] found that morphological differentiation between populations of Prosopis flexuosa in the Monte phytogeographic province was possible thanks to the great weight variables had like length of leaflet and the relationship between length of pinnae and width of leaflet.

Moreover, Burghardt et al. [53] found that variables such as length and width of pinnae and length of leaflet, evaluated by principal component analysis, were suitable to differentiate seedlings of 8 Prosopis species, grown under uniform conditions.

In this study for morphological analysis of the offspring, 8 of the 12 variables were required and evaluated at leaf level and 5 of the 6 variables were recorded in the nursery to achieve adequate differentiation. Length of leaflet along the width and area of the same variables were the most important in the discriminant analysis.

From the morphological analysis of the mothers it was possible to group the apparent morphological continuum into five groups with an error level of $24 \%$. This error was primarily attributable to the variability in group 3 and less in group 4, both groups classified as intermediate. Groups 1 and 2 were the most homogeneous, since the error rate was very low (4 to $5.6 \%$ ), followed by group $5(15 \%)$.

By studying the seedlings in the nursery (offspring) and trying to regroup under the classification for maternal individuals it was observed that the error in the correct allocation increases, mainly in groups of intermedi- ate characteristics.

Although the formation of these clusters in offspring cannot be confirmed, multivariate analysis of canonical correlation for each morphological group reflects the morphological groups which best explain the variability for each pair of canonical axes were groups 3 and 4 being the most variable and presenting the highest values of $R^{2}$. These values indicate that the high variability found in mothers is strongly associated with high variability found in offspring, in other words, the observed variability in both sets follows a certain linear relation, or one might say, a continuous order.

At this level of analysis, variables such as those cited by Burghardt et al. [53] are include. The length of the pinnae, the number and length of leaflets in set of the offsprings and for the set of mothers, the variables that repeated the most in the different associations, were the number of knuckles, the thickness of the fruit, length of leaflet and the ration length/width of leaflet.

Each pair of canonical axes was different for each morphological group, confirming identity of morphological groups.

The differentiation between populations in morphological groups in each region is linked to the fact that the proportion of each morphological group in each area is different as well as is the ecological and human conditions.

In 1999, in zones 1 and 2 the livestock of cattle, goats and sheep dominated over agiculture. The abundance of Prosopis nigra confirms the existence of cattle that considers this species little palatable and hence the percentage of this group is high $(30 \%)$ in these regions.

Zone 3, apart from being in an ecotone between semiarid and arid region, this is an area where agricultural activity was the greatest on livestock. Thus, according to comments from the locals, the whites "algarrobos" were left on seats and helmets stay, because they provided a better shade and they were not attacked by drills, as it happened with the black "algarrobos" ( $P$. flexuosa and $P$. nigra). On the other hand, the region 4 is a mixed production area, where there is intensive agriculture (vineyards, olive and other fruit) in combination with large cattle ranches.

Both regions are very disturbed by humankind. In them; the native forest has been reduced to isolated patches of adults or elderly individuals. In many cases the larger individuals and portage have been left, which the locals called "pantosos" and coinciding trees are qualified within the intermediate groups, hence these regions have the highest values of diversity, granted mainly by such intermediate groups which continue to mingle with the group of blacks and whites.

The morphological groups arising from the ordering of 
the mothers (determined by numerical taxonomy and confirmed with a certain error of misclassification by the discriminant analysis, both mothers and in offspring) are homogeneous groups and it is considered that each of them has a unique identity. This unique identity is not consistent with the classification made from classical taxonomy.

The classical taxonomy in this study determined that there are 16 taxa, while the morphological study sums it up in 5 morphological groups $[54,55]$. While it is always necessary to specify the scientific name of each group in this study it is assumed, for the homogeneity of the material, that group 1 consists of Prosopis alba, group 2 is Prosopis chilensis, group 3 is a group of individuals of intermediate characteristics between white "algarrobo"; $P$. alba and P. chilensis; group 4 is formed by individuals from classical taxonomy classified as hybrids between a white and black "algarrobo" ( $P$. flexuosa and P. nigra) and group 5 consists of Prosopis nigra.

\section{Conclusions}

The "algarrobos", present in the contact area of Prosopis chilensis-P. flexuosa-P. alba-P. nigra in the Semiarid Chaco of northern Cordoba and Southeast Santiago del Estero, form morphologically defined groups.

Morphological studies of the offspring of the "algarrobos" present in the contact area of Prosopis chilensisP. flexuosa-P. alba-P. nigra in the Semiarid Chaco of northern Cordoba and Southeast Santiago del Estero confirm the existence of morphologically defined groups.

\section{Acknowledgements}

The autors wish to thank to Dr. Ramón Palacios (Laboratorio de Plantas Vasculares de la Universidad Nacional de Buenos Aires) for taxonomy determination. They also acknowledge the IFRGV-CIAP-INTA. This work was supported by Banco Nacional de Germoplama de Prosopis and INTA Proyect 357.

\section{REFERENCES}

[1] W. Jackson, S. Maginnis and C. Elliot, "Prefacio," In: D. Lamb and D. Gilmour, Eds., Rehabilitation and Restoration of Degraded Forest, IUCN-WWF, Swiss-Grand, 2003, $110 \mathrm{p}$.

[2] S. de Ambiente and D. S. de la Nación, "Dirección de Impacto Ambiental y Social. Estadísticas Ambientales," 2010. http://www.ambiente.gov.ar/?id seccion $=211$

[3] C. Palmberg-Lerche and S. Hald, "La Ordenación de los Recursos Genéticos Forestales: Situación y Desafíos," Unasylva, Vol. 5.1, No. 4, 2000, pp. 27-33.

[4] N. B. Julio, "Estudios Alozímicos Sobre Variabilidad, Estructura y Diferenciación Genética en Prosopis chilen- sis (Leguminosae, Mimosoideae) y Especies Relacionadas", Tesis de Doctorado en Ciencias Biológicas, UNC, Facultad de Ciencias Exactas, Físicas y Naturales, Argentina, 2000

[5] N. M. Pasiecznik, P. Felker, P. J. C. Harris, L. N. Harsh, G. Cruz, J. C. Tewari, T. K. Cadore and L. J. Maldonado, "The Prosopis juliflora-prosopis pallida Complex: A Monograph," HDRA, Coventry, 2001.

[6] A. Burkart, "A Monograph of the Genus Prosopis (Leguminosae subfam. Mimosoideae) (Part 1 and 2). 'Catalogue of the Recognized Species of Prosopis'," Journal of the Arnold Arboretum, Vol. 57, 1976, pp. 219-249; 450525.

[7] R. Palacios, M. A. Agulló, M. P. Mom, S. Torregrosa and P. Picca, "Especies del Género. Taxonomía. Prosopis en Argentina, Documento Preliminar Elaborado Para el Primer Taller Internacional Sobre Recurso Genético y Conservación de Germoplasma en Prosopis," FAO, FCAUNC y FCEy N-UBA, Córdoba, 3-8 de Octubre 1988, pp. 15-96.

[8] V. Grant, "Plant Speciation," Columbia University Press, New York, 1981

[9] R. A. Palacios and L. D. Bravo, "Hibridación Natural en Prosopis (Leguminosae) en la Región Chaqueña Argentina. Evidencias Morfológicas y Cromatográficas," Darwiniana, Vol. 23, No. 1, 1981, pp.3-35.

[10] B. O. Saidman, "Las Isoenzimas en el Estudio de la Variación Genética y las Afinidades Entre Especies de Prosopis," Boletín de Genética del Instituto Fitotécnico de Castelar, Vol, 16, 1993, pp. 25-37.

[11] A. R. Verga, "Genetic Study of Prosopis chilensis y Prosopis flexuosa (Mimosaceae) in the Dry Chaco of Argentina," Tesis Doctoral, Göttingen Researh Notes in Forest Genetics, Abteilung für Forstgenetik und Forstpflanzensüchtung der Universität Göttingen, Göttingen, 1995.

[12] A. R. Verga and H.-R. Gregorius, "Genetic Consistency of Morphological Differentiation in the Prosopis chilensis-P. flexuosa Complex," Silvae Genetica, Vol. 56, No. 2, 2007, pp. 45-51.

[13] A. R. Verga, C. López, M. Navall, M. J. Joseau, C. Gómez, O. Royo, W. Degano and M. Marcó, "Caracterización Morfológica de los Algarrobos (Prosopis spp.) en las Regiones Fitogeográficas Chaqueña y Espinal Norte de Argentina," Quebracho, Vol. 17, No. 1-2, 2009, pp. 31-40.

[14] C. A. Naranjo, L. Poggio and S. Enus Zeiger, "Phenol Chromatography, Morphology and Cytogenetics in Three Species and Natural Hybrids of Prosopis (Leguminosae, Mimosoidae)", Plant Systematics and Evolution, Vol. 144, No. 3-4, 1984, pp. 257-276. http://dx.doi.org/10.1007/BF00984137

[15] J. H. Hunziker, L. Poggio, C. A. Naranjo and R. A. Palacios, "Cytogenetics of Some Species and Natural Hybrids in Prosopis (Leguminosae)," Canadian Journal of Genetics and Cytology, Vol. 17, No. 2, 1975, pp. 253-262.

[16] J. H. Hunziker, C. Naranjo, R. A. Palacios and L. Poggio, "Chromosomal Cytology and Hybridization," In: B. Simpson, Ed., Mesquite, Its biology in Two Desert Scrub 
Ecosystems (US/IBP Synthesis Series)," Dowden, Hutchinson and Ross, Inc., Stroudsburg, 1977, pp. 56-59.

[17] J. H. Hunziker, B. O. Saidman, C. A. Naranjo, R. A. Palacios, L. Poggio and A. D. Burghardt, "Hybridization and Genetic Variation of Argentine Species of Prosopis (Leguminosae, Mimosoidae)," Forest Ecology and Management, Vol. 16, No. 1-4, 1986, pp. 301-315. http://dx.doi.org/10.1016/0378-1127(86)90030-7

[18] J. Morello, N. Crudeli and M. Saraceno, "Los Vinales de Formosa (República Argentina). La Colonizadora Leñosa Prosopis ruscifolia Gris," Serie Fitogeográfica, Vol. 11, INTA, 1971.

[19] L. I. Ferreyra, "Estudio de la Variabilidad y la Diferenciación Genética por Medio de Técnicas de Isoenzimas y RAPD en Poblaciones Naturales de Especies e Hibridos de Género Prosopis (Leguminosae)", Tesis Para Optar al grado de Doctor en Ciencias Biológicas, Universidad de Buenos Aires, Buenos Aires, 2001.

[20] M. V. Vega and P. Hernández, "Molecular Evidence for Natural Interspecific Hybridization in Prosopis," Agroforestry Systems, Vol. 64, No. 3, 2005, pp. 197-202. http://dx.doi.org/10.1007/s10457-004-2028-2

[21] B. O. Saidman, "Isoenzymatic Studies of Alcohol Dehydrogenase and Glutamate Oxalacetate Transaminase in four South American Specis of Prosopis and Their Natural Hybrids," Silvae Genetica, Vol. 35, No. 1, 1986, pp. 3-10.

[22] C. Bessega, "Estudios Isoenzimáticos en Especies Americanas del Género Prosopis (Leguminosae)". Tesis de Maestría, Universidad de Buenos Aires, Buenos Aires, 1997.

[23] O. T. Solbrig, K. Bawa, N. J. Carman, J. H. Hunziker, C. A. Naranjo, R. A. Palacios, L. Poggio and B. B. Simpson, "Patterns of Variation," In: B. B Simpson, Ed., Mesquite, Its biology in Two Desert Scrub Ecosystems (US/IBP Synthesis Series)," Dowden, Hutchinson and Ross, Inc., Stroudsburg, 1977, pp. 44-60.

[24] C. A. Naranjo and S. Enus Zeiger, "Cromatografía de Fenoles y Morfología en Especies e Híbridos de Prosopis de la Pampa," XIX Jornadas Argentina de Botánica, Santa Fe, 19-23 Sepember 1983, p. 32.

[25] A. D. Burghardt and R. A. Palacios, "Estudio Electroforético en Cuatro Especies del Género Prosopis (Leguminosae)," Boletín de la Sociedad Argentina de Botánica, Vol. 27, No.1-2, 1991, pp. 43-48.

[26] A. D. Burghardt, "Prosopis L. Caracterización Electroforética de sus Especies," Tesis Doctoral, Universidad de Buenos Aires, Buenos Aires, 1992.

[27] B. O. Saidman, "Estudio de la Variación Alozímica en el Género Prosopis," Tesis doctoral, Universidad de Buenos Aires, Buenos Aires, 1985.

[28] B. O. Saidman, "La Electroforesis de Isoenzimas Para la Medición de la Variabilidad Genética en Especies de Prosopis," Documento Preliminar Elaborado Para el Primer Taller Internacional Sobre Recurso Genético y Conservación de Germoplasma en Prosopis, Córdoba, 3-8 de Octubre 1988, pp. 107-118.
[29] B. O. Saidman and J. C. Vilardi, "Genetic Variability and Germoplasm Conservation in the Genus Prosopis," In: S. Puri, Ed., Nursery Technology of Forest Tree Species of Arid and Semiarid Regions, Winrock-Oxford \& IBH Publishing Co. PVT. Ltd., New Delhi, Bombay, Calcuta, 1993, pp. 187-198.

[30] B. O. Saidman and J. C. Vilardi, "Analysis of the Genetic Similarities among Seven Species of Prosopis (Leguminosae: Mimosoideae)", Theoretical and Applied Genetics, Vol. 75, No. 1, 1987, pp. 109-116. http://dx.doi.org/10.1007/BF00249150

[31] E. Anderson, "Introgressive Hybridization," Wiley, Nueva York, 1949.

[32] M. Cony, "Genetic Potential of Prosopis in Argentina for Its Use in Other Countries. Prosopis: Semiarid Fuelwood and Forage Tree," Building Consensu for the Disenfranchised. US National Academy of Sciences Building, Washington DC, 13-15 March 1996, pp. 3-24.

[33] FAO, "Proyecto FAO/IBPGR Sobre Recursos Genéticos de Especies Arbóreas Productoras de Leña Para el Mejoramiento de la Vida Rural," Información Sobre Recursos Genéticos Forestales, Vol. 10, 1981, pp. 36-38.

[34] C. Palmerg, "Proyecto FAO Sobre Recursos Genéticos de Especies Arbóreas Para el Mejoramiento de la Vida Rural en Zonas Aridas y Semiáridas," In: M. H. Habit, Ed., Estado Actual del Conocimiento Sobre Prosopis Tamarugo, Arica, Chile, 1985, pp. 203- 207.

[35] U. O. Karlin, R. Coirini and R. R. Zapata, "Recolección de Germoplasma. Conservación de Recursos Forestales Nativos en Argentina," In: G. E. Verzino and M. J. Joseau Eds., El Banco Nacional de Germoplasma de Prosopis, Córdoba, 2005, pp. 25-38.

[36] V. Mazzuferi, P. Ingaramo and J. Joseau, "Tratamiento de Calor Para el Secado de Frutos y el Control de Insectos en Prosopis chilensis," Agriscientia, Vol. 11, 1994, pp. 4950.

[37] M. Naumann, "Pequeño Atlas Argentino con el Gran Chaco. Programa de Acción Nacional de Lucha Contra la Desertificación PAN," Convenio SRNyDS-INTA-GTZ, Imprenta Bavaria, Bariloche, 1999.

[38] J. Morello and J. Adamoli, "Las Grandes Unidades de Vegetación y Ambiente del Chaco Argentino. Primera parte: Objetivos y Metodología," INTA, Serie Fitogeográfica, 1968.

[39] M. Cabido and M. Zak, "Vegetación del Norte de Córdoba. Secretaria de Agricultura, Ganadería y Recursos Renovables de Córdoba," Córdoba, 1999.

[40] M. de Desarrollo Social and M. Ambiente, "Estudio Integral de la Región del Parque Chaqueño," 2nd Edición, Informe Esencial, Proyecto Bosques Nativos y Areas Protegidas, Red Agroforestal Chaco Argentina, 1999.

[41] A. Ragonese, "Vegetación y Ganadería en la República Argentina,” Colección Científica del INTA, 1967.

[42] F. Latzina, "Géographie de La République Argentine," Félix Lajouane, Éditeur, 1890.

[43] A. De Fina, "Datos Agroclimáticos de la República Argentina", Institute for Domestic and International Affairs 
(IDIA), Vol. 337-342, 1976, pp. 57-186.

[44] J. Morello, "La Provincia Fitogeográfica del Monte," Opera Lilloana, Tucumán. 1959.

[45] A. R. Verga, "Hojas. Programa Para la Medición de Caracteres Morfológicos de Hojas", INTA. IFFIVE. Córdoba, 2000.

[46] A. R. Verga, "Taxón. Programa de Taxonomía Numérica en Base a la Distancia Morfológica $d_{m}$ Cartilla de Uso," Estación Experimental Agropecuaria INTA Junín, Mendoza, 1996.

[47] NTSYS, Version 2.02. Applied Biostatistics Inc., EUA, 1997.

[48] R. A. Johnson and D. W. Wichern, "Applied Multivariate Statistical Analysis," 2nd Edition, Prentice Hall International Inc., Upper Saddle River, 1993.

[49] "Sas Online Doc. Version 8," SAS Institute Inc, Cary, 1999.

[50] H. Hotelling, "Relations between Two Sets of Variables," Biometrika, Vol. 28, No. 3/4, 1936, pp. 321-377.

[51] InfoStat, "Infostat/Estudiantil," Grupo Infostat/FCA, Uni- versidad Nacional de Córdoba, Córdoba, 2007.

[52] N. G. Mantován, "Variabilidad Intraespecífica de los Patrones Fenológicos de Prosopis flexuosa en la Provincia Fitogeográfica del Monte," Reunión Nacional del Algarrobo. III Reunión de la Asociación Argentina de Prosopis, Mendoza, 14-17 de noviembre 2000, p. 30.

[53] A. D. Burghardt, M. M. Brizuela and R. A. Palacios, "Variabilidad en Plántulas de Algunas Especies de Prosopis (Fabaceae). En Busca de Descriptores Morfológicos," Multequina, Vol. 9, 2000, pp. 23-33.

[54] M. J. Joseau., A. R. Verga and M. del Pilar Díaz, "Los Recursos Genéticos de Prosopis en el Corredor Que une el Chaco Árido con el Semiárido Entre las Provincias de Córdoba y Santiago del Estero," Genética y Mejoramiento, Vol. 21, 2004, pp. 207-211.

[55] M. J. Joseau and F. F. Castro Schüle, "Caracterización del Género Prosopis," In: G. E. Verzino and M. J. Joseau. Eds, Conservación de Recursos Forestales Nativos en Argentina. El Banco Nacional de Germoplasma de Prosopis, Vol. 8, Córdoba, 2005, pp. 81-88. 